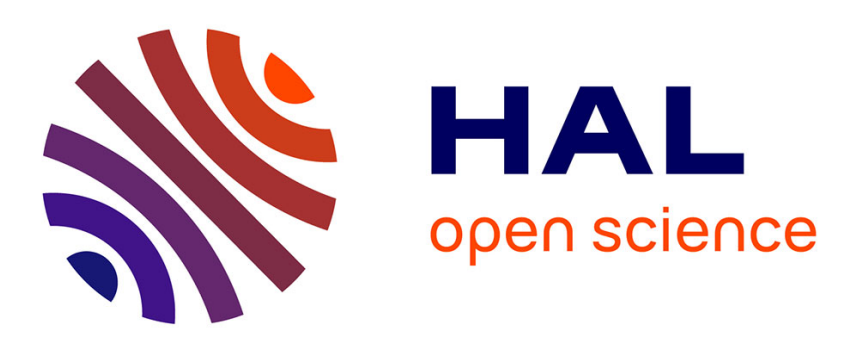

\title{
Mercury concentrations and trophic relations in sharks of the Colombia Pacific
}

Natalia Vélez, Sandra Bessudo, Dalia Barragán-Barrera, Felipe Ladino, Paco Bustamante, Andrea Luna-Acosta

\section{- To cite this version:}

Natalia Vélez, Sandra Bessudo, Dalia Barragán-Barrera, Felipe Ladino, Paco Bustamante, et al.. Mercury concentrations and trophic relations in sharks of the Colombia Pacific. Marine Pollution Bulletin, 2021, 173, pp.113109. 10.1016/j.marpolbul.2021.113109 . hal-03489458

\section{HAL Id: hal-03489458 https://hal.science/hal-03489458}

Submitted on 30 Dec 2021

HAL is a multi-disciplinary open access archive for the deposit and dissemination of scientific research documents, whether they are published or not. The documents may come from teaching and research institutions in France or abroad, or from public or private research centers.
L'archive ouverte pluridisciplinaire HAL, est destinée au dépôt et à la diffusion de documents scientifiques de niveau recherche, publiés ou non, émanant des établissements d'enseignement et de recherche français ou étrangers, des laboratoires publics ou privés. 


\section{Mercury concentrations and trophic relations in sharks of the Colombian Pacific}

Natalia Vélez ${ }^{1,2, *}$, Sandra Bessudo, ${ }^{1, *}$, Dalia C. Barragán-Barrera ${ }^{3,4,5}$, Felipe Ladino ${ }^{1}$, Paco Bustamante $^{6,7}$, Andrea Luna-Acosta ${ }^{2}$

${ }^{1}$ Fundación Malpelo y Otros Ecosistemas Marinos, Parques Nacionales Naturales de Colombia, Carrera 11 \# 87-51, Bogota, Colombia.

${ }^{2}$ Departamento de Ecología y Territorio, Facultad de Estudios Ambientales y Rurales, Pontificia Universidad Javeriana, Transversal 4 \# 42-00, Bogotá, Colombia.

${ }^{3}$ Centro de Investigaciones Oceanográficas e Hidrográficas del Caribe-CIOH, Dirección General Marítima, Barrio Bosque, Sector Manzanillo Escuela Naval de Cadetes "Almirante Padilla", Cartagena de Indias, Colombia.

${ }^{4}$ Corporation Center of Excellence in Marine Sciences-CEMarin, Carrera 21 \# 35-53, Bogotá, Colombia.

${ }^{5}$ Fundación Macuáticos Colombia, Calle 27 \# 79-167, Medellín, Colombia.

${ }^{6}$ Littoral Environnement et Sociétés (LIENSs) UMR 7266 CNRS- La Rochelle Université, 2 rue Olympe de Gouges, 17000 La Rochelle, France.

${ }^{7}$ Institut Universitaire de France (IUF), 1 rue Descartes 75005 Paris, France

* These authors contributed equally to this work.

Corresponding author: n.velez858@gmail.com 


\begin{abstract}
Sharks are fished for human consumption in Colombia, and fins are exported illegally to international markets. The goal was to identify differences in total mercury (THg) concentrations in fins and muscles of shark species seized in the Buenaventura port (Colombian Pacific), and to assess potential human health risks related to shark consumption. Seven species were considered in this study: Pelagic Thresher (Alopias pelagicus), Pacific Smalltail Shark (Carcharhinus cerdale), Brown Smoothhound (Mustelus henlei), Sicklefin Smoothhound (Mustelus lunulatus), Scalloped Bonnethead (Sphyrna corona), Scalloped Hammerhead (Sphyrna lewini), and Bonnethead Shark (Sphyrna tiburo), and THg was analyzed in shark tissues. $24 \%$ muscle samples concentrations were above international recommended limits for human consumption, especially for A. pelagicus and S. lewini. Stable isotopes $\left(\delta^{13} \mathrm{C}\right.$ and $\left.\delta^{15} \mathrm{~N}\right)$ analysis showed a foraging overlapping in coastal habitats, where overfishing usually occurs. This study provides useful scientific information to develop management plans for sharks in Colombia and neighboring countries.
\end{abstract}

Key words: Sharks, total mercury, stable isotopes, human health risks, trophic ecology, Colombia Pacific. 


\section{Introduction}

Many shark species are currently threatened, due to the degradation of their habitat, overfishing, bycatch, and especially finning, considered as the main cause of shark population decline worldwide (Clarke et al., 2007; Dulvy et al., 2014). Finning is a fishing activity that consists in fishing sharks, removing their fins, and returning the rest of the body to the ocean (Clarke et al., 2007; Hernandez Betancourt et al., 2011; Helfman and Burgess, 2014). Even if this is an illegal activity in many countries, finning continues on a large scale, and it is estimated that between 26 and 73 million of sharks are traded worldwide annually (Clarke et al., 2007). This is due to the high price and demand of this resource in Asian markets, particularly in Hong Kong (Clarke et al., 2004), where a shark fin costs $\sim$ US \$42.00 per kilo (Jaiteh et al., 2017), and a shark fin soup costs between US \$250 and US \$1800 (Nalluri et al., 2014; The 8 Restaurant, 2017).

In countries like Colombia, shark is part of food in some coastal locations, but fin soup is not consumed. However, finning is an activity that generates strong incomes due to their high commercial value in the Pacific region (Ross Salazar et al., 2019). Fin prices in Colombia are approximately US \$40 per kilo, in contrast to shark meat prices of US \$1.5 per kilo (Ross Salazar et al., 2019). Between 2005 and 2017, an average of $317,974 \mathrm{~kg}$ of sharks were caught in Colombia (Ross Salazar et al., 2019), even though in 2013 shark finning was prohibited in Colombia (Rodríguez Ortiz et al., 2016). Unfortunately, this activity has continued illegally, putting at high risk shark populations (Caldas Aristizabal et al., 2010; Jaiteh et al., 2017).

Recent studies suggest that prices of shark fins have fallen sharply since 2012 (Eriksson and Clarke, 2015) due, in part, to the conservation campaigns that have raised awareness of the effects of finning on shark populations (Whitcraft et al., 2014) and concerns about food safety (Fabinyi and Liu, 2014). Studies of THg concentrations in shark tissues have reported high concentrations of this metal (e.g., Kim et al., 2016; Le Bourg et al., 2019) that exceed the safety level for human consumption of $1000 \mathrm{ng} \mathrm{g}^{-1} \mathrm{Ww}$ determined by organizations such as the Food and Agriculture Organization of the United Nations (FAO) and the World Health Organization (WHO) (FAO/WHO, 2011). These have generated a concern about human health risks to shark consumption, leading this distress as a conservation strategy to reduce shark fin demand (WHO, 2006; Escobar-Sanchez et al., 2010; Fabinyi and Liu, 2014; Man 
et al., 2014; Nalluri et al., 2014). The main concern is because THg is toxic for humans as it is a cumulative poison that bioaccumulates in the body (Matulik et al., 2017). Because THg is biomagnified by trophic transfers in food webs, top predators such as sharks, generally show very high $\mathrm{THg}$ concentrations in their tissues in comparison to other seafood products (Nalluri et al., 2014).

Because of both legal and illegal gold extraction (Tubb, 2015; Castellanos et al., 2016; Palacios-Torres et al., 2018), Colombia is the third country that emits more THg to the environment after China and Indonesia (Telmer and Veiga, 2009), exceeding the amounts issued by the three main gold producers together, minus China, which are Russia, Australia, and the United States (World Gold Council, 2020). The Choco region, which is located in the Colombian North Pacific coast, is the second largest producer of gold in Colombia and it has been detected that $90 \%$ of the gold produced comes from alluvial operations (Massé and McDermott, 2017). The releases from gold mining may contribute to the $\mathrm{THg}$ contamination of the marine environment and consequently of the whole food webs up to sharks. Assessing THg concentrations in shark populations from the Colombian Pacific will allow to know the current contamination status in these species and the ecosystems they exploit and forage on, and also will provide relevant data about potential health risks related to shark consumption. International authorities such as FAO/WHO (Food and Agriculture Organization/World Health Organization) and Colombian agencies such as Invima (National Institute for Food and Drug Surveillance) are responsible for controlling these limits of $\mathrm{THg}$ in food and informing the population about the possible risks of THg in human health. Findings on this sense may also contribute to improve conservation and management strategies for shark populations that have been carried out in the Colombian Pacific, such as the National Action Plan for the Conservation and Management of Sharks, Rays, and Chimaeras of Colombia (PAN-Tiburones Colombia) (Caldas Aristizabal et al., 2010). Confirmation of $\mathrm{THg}$ concentrations in shark tissues from Colombia, could be used as a conservation strategy to reduce their international demand and national overfishing.

Therefore, for this study we assessed: (1) THg concentrations in fins and muscles of seven shark species seized in the Buenaventura port (Colombian Pacific), which include the Pelagic Thresher (Alopias pelagicus), Pacific Smalltail Shark (Carcharhinus cerdale), Brown Smoothhound (Mustelus henlei), Sicklefin Smoothhound (Mustelus lunulatus), Scalloped 
Bonnethead (Sphyrna corona), Scalloped Hammerhead (Sphyrna lewini), and Bonnethead Shark (Sphyrna tiburo); (2) potential human health risks related to fin and muscle consumption of any of these species; and (3) trophic ecology of the seven species of sharks by analyzing trophic interactions and possible overlaps of their ecological niche using chemical tracers of habitat and $\operatorname{diet}\left(\delta^{13} \mathrm{C}\right.$ and $\delta^{15} \mathrm{~N}$, respectively). Assessing trophic ecology and monitoring of $\mathrm{THg}$ in sharks captured in the Colombian Pacific and seized in the Buenaventura port, represents important precautionary measures to facilitate shark conservation in Colombia and neighboring countries.

\section{Materials and methods}

\subsection{Study area}

The Buenaventura port is located on the Colombian Pacific coast (Fig. 1). Fisheries on this region are characterized by sustenance fishing marketed in local markets ( $\mathrm{P}^{\prime}$ erez-Valbuena, 2007). Particularly for sharks, a large number of by-products such as jaw, vertebrae, meat, and liver are marketed in local markets (Caldas Aristizabal et al., 2010) as ornaments, food, or a nutritional source of omega-3 fatty acids (Maggie and Covington, 2004), respectively; however, fins are mostly marketed in international markets (Navia et al., 2016). These fins are exported illegally mainly from the Buenaventura port to Hong Kong and to China (Ross Salazar et al., 2019), so most of shark fin seizures in Colombia take place in this port (Estupiñan-Montaño et al., 2017: Ross Salazar et al., 2019). For this reason, samples used for this study came from shark fin seized on the coast of the Buenaventura port.

\subsection{Shark tissue collection and sample preparation}

A total of 175 samples of two different shark tissues were collected: 130 fin and 45 muscle samples. Shark fin and muscle samples seized at the Buenaventura port, were collected by researchers from the Malpelo Foundation and rangers from the Unit of National Natural Parks of Colombia between 2009 and 2013. For the purposes of this study, the seven species of sharks that had the highest collection frequency were selected. 
Among the species selected to analyze fin samples, were included: (1) Pelagic Thresher ( $A$. pelagicus) a highly migratory species from the epipelagic zone, which is in the Endangered category (EN) according to the IUCN (Rigby et al., 2019a, 2019b); (2) Pacific Smalltail Shark (C. cerdale), a coastal species that lives in estuarine ecosystems of the continental shelf, in shallow waters and with muddy substrates, cataloged by the IUCN as Critically Endangered (CR) (Pollom et al., 2020); (3) Brown Smoothhound (M. henlei), which inhabits mainly in coastal waters and in the open sea on the continental shelves, cataloged as Least Concern (LC) (Pérez-Jiménez et al., 2016a, 2016b); (4) Sicklefin Smoothhound (M. lunulatus), a species that is found near the coast and categorized as LC due mainly to incidental fishing (Pérez-Jiménez et al., 2016a); (5) Scalloped Bonnethead (S. corona), which resides on the continental shelf in shallow estuarine habitats, and is listed as Near Threatened (NT) mainly due to artisanal fishing (Mycock, 2004); (6) Scalloped Hammerhead (S. lewini), a coastal and semi-oceanic pelagic species found on continental and insular shelves, and in deeper waters up to $275 \mathrm{~m}$ depth, cataloged as Critically Endangered (CR) mainly due to finning (Rigby et al., 2019a); and (7) Bonnethead Shark (S. tiburo), an estuarine species found in shallow bays that is listed as LC mainly due to commercial, recreational, and incidental fisheries (Compagno, 1984; Cortés et al., 2016). Additionally, muscle samples were collected for A. pelagicus and S. lewini, two species whose threat status is the most critical (Supplementary Table S1).

Collected samples were preserved in $70 \%$ ethanol and stored at $-20^{\circ} \mathrm{C}$ for subsequent laboratory analysis. Following Barragan-Barrera et al. (2019), samples were left on a bench to let alcohol evaporated, then were homogenized, and freeze-dried to perform posterior $\mathrm{THg}$ and isotopic analyses (Fontaine et al., 2015; Barragan-Barrera et al., 2019).

\subsection{Mercury analyses}

THg measurements were conducted using an atomic absorption spectrometer AMA-254 (Altec (C) Advanced Mercury Analyzer-254). For each sample, at least a minimum of two aliquots of 1 to $5 \mathrm{mg}$ of homogenized dry tissue subsamples were analyzed in order to estimate average THg concentrations (Aubail et al., 2013; Angel-Romero et al., 2018; Barragan-Barrera et al., 2019). Some measurements needed to be repeated until having 
analytical differences below $10 \%$. The analytical quality of the THg measurements by the AMA-254 was evaluated by the analysis of blanks and certified reference material (CRM) TORT-2 (Reference Material of lobster hepatopancreas marine certified by the National Research Council of Canada) at the beginning and at the end of the analytical cycle, and after running the analysis of 15 samples. Blanks were negligible and agreement was considered satisfactory. The CRM measured concentration was $0.305 \pm 0.025 \mu \mathrm{g} \mathrm{g}^{-1}(\mathrm{n}=20)$, with a percentage of average recovery of $104 \%$. THg measurements are presented in $\mathrm{ng} \mathrm{g}^{-1}$ on a wet weight basis (ww) and the detection limit was $0.5 \mathrm{ng}$.

\subsection{Conversion of dry weight to wet weight in shark fins and muscles}

Threshold values defined by regulatory guidelines of health agencies are established in wet weight (ww). However, concentration measurements of contaminants and stable isotope ratios $\mathrm{C}$ and $\mathrm{N}$ are usually made in dry material in order to avoid differences in results due to variations in water content of the individuals analyzed (Bryan, 1984; Fisk et al., 2002; Cresson et al., 2015; McKinney et al., 2016). For this reason, THg concentrations measured in dry weight $(\mathrm{dw})$ in this study were transformed to wet weight (ww) based on the following formula:

$$
C_{w w}=C_{d w} \times\left(\frac{100-\% H}{100}\right)
$$

where $\mathrm{C}_{\mathrm{ww}}$ and $\mathrm{C}_{\mathrm{dw}}$ are concentrations expressed in wet and dry weight respectively, and $\% \mathrm{H}$ is the percentage of humidity that normally oscillates around $80 \%$ for fish species (Murray and Burt, 1969; Hislop et al., 1991; Payne et al., 1999; Environmental Protection Agency, 2011).

\subsection{Risk assessment for consumption of shark fins and muscles}

THg concentrations of each species in fins and muscles were evaluated considering the maximum limit of $\mathrm{THg}$ in fish for human consumption by the Food and Agriculture 
Organization (FAO) and the World Health Organization (WHO), established as $1000 \mathrm{ng} \mathrm{g}^{-1}$ ww for top predators, such as sharks (FAO/WHO, 2011).

Human health risks derived from the consumption of fins and shark muscles were evaluated based on the non-carcinogenic risk ratio or Target Hazard Quotient (THQ). THQ is a specific dose ratio of a contaminant (in this case $\mathrm{THg}$ ) at a reference dose level. THQ $\leq 1$ indicates that there are no adverse health effects, while THQ > 1 indicates possible adverse health effects (United States Environmental Protection Agency (USEPA), 1989, 2000). THQ is calculated using the following equation (United States Environmental Protection Agency (USEPA), 1989; Vieira et al., 2011):

$$
T H Q=\frac{E F r \times E D \times I R \times M C}{R f D \times B W \times A T},
$$

where THQ is dimensionless; EFr is the frequency of exposure (365 days per year; Storelli et al., 2008); ED is the duration of the exposure (70 years, as the average human life time; Storelli et al., 2008); IR is the rate of food ingestion $\left(33.410^{-3} \mathrm{~kg}\right.$ per day per person for the world; Food and Agriculture Organization (FAO), 2009); MC is the THg shark tissue concentration $(\mathrm{mg} / \mathrm{kg})$; RfD is the oral reference dose $\left(3.010^{-4} \mathrm{mg} / \mathrm{kg} / \mathrm{day}\right.$ for $\mathrm{THg}$; Nadal et al., 2008; United States Environmental Protection Agency (USEPA), 2010); BW is the human body weight $(\mathrm{kg})$ : for this research, it was assumed an average body weight of $60 \mathrm{~kg}$ for an adult between 20 and 65 years and an average weight of $30 \mathrm{~kg}$ for a child between one and 19 years (Vieira et al., 2011); AT is the number of days during which the exposure is averaged (365 days $\times \mathrm{ED}$, according to REF). THQ was calculated with the average $\mathrm{THg}$ concentration (average THQ) and with the maximum and minimum values of $\mathrm{THg}$ concentrations for each species (maximum and minimum THQ, respectively).

Furthermore, the average, minimum, and maximum estimated weekly intake (EWI) of $\mathrm{THg}$ was calculated for each species, and these results were compared to the provisional tolerable weekly intake (PTWI) recommended by the Joint FAO/WHO Expert Committee on Food Additives for methylmercury ( $\mathrm{MeHg}$ ), since this organic form represents usually $90 \% \mathrm{of} \mathrm{THg}$ in fish muscles (Bloom, 1992; Adams and McMichael, 1999) and 70\% in fins (Garcia Barcia et al., 2020). The Joint FAO/WHO Expert Committee stated that the PTWI is $1.6 \mathrm{ng} \mathrm{g}^{-1}$ body 
weight (bw) for the most susceptible human population such as children and women of childbearing age to protect an embryo (JECFA, 2004). Regarding the adult population, the committee considers that the intake of $\mathrm{THg}$ can be up to two times more $\left(3.2 \mathrm{ng} \mathrm{g}^{-1}\right.$ of body weight) (WHO, 2006). The EWI was determined with the following equation (Mohammed and Mohammed, 2017):

$$
E W I=\frac{Q_{f i s h} \times M C}{B W},
$$

where $\mathrm{Q}_{\text {fish }}$ is the weekly amount of shark consumed $(\mathrm{kg}), \mathrm{MC}$ is the concentration of the contaminant in the shark piece consumed ( $\mathrm{ng} \mathrm{g}^{-1} \mathrm{Ww}$ ), and BW is the human body weight (kg; $60 \mathrm{~kg}$ for adults between 20 and 65 years, and $30 \mathrm{~kg}$ for children between one and 19 years; Vieira et al., 2011). For adults, it was considered a consumption of $37.51 \mathrm{~g}$ of fins in a portion of fish soup (Man et al., 2014) and of $234 \mathrm{~g}$ of muscles in a plate (Food and Agriculture Organization (FAO), 2009). For children, knowing that food consumption at this early stage of life is lower than an adult (Leung et al., 2000), $37.51 \mathrm{~g}$ of fins and $200 \mathrm{~g}$ of muscles were considered (Man et al., 2014). A rate consumption of one portion per week was considered for both adults and children (Man et al., 2014).

\subsection{Stable isotope analysis}

Because lipids are present in shark tissues and can alter values of $\delta^{13} \mathrm{C}$ (De Niro and Epstein, 1977), all samples were delipidated before analysis of stable isotopes. For this, three repetitions of lipid removal in $4 \mathrm{ml}$ of cyclohexane were carried out in each sample, stirring for $10 \mathrm{~min}, 5 \mathrm{~min}$ of centrifugation, and finally drying in an oven at a maximum temperature of $45^{\circ} \mathrm{C}$ (Chouvelon et al., 2011). Then, between 0.2 and $0.4 \mathrm{mg}$ of each delipidated sample were weighted in tin cups. Stable isotope measurements were performed on a Delta V Advantage IRMS isotopic mass spectrometer (Thermo Scientific, Bremen, Germany) coupled to an EA 1112 Flash elemental analyzer (Thermo Scientific, Germany). The reference gas was calibrated with international reference materials including acetanilide and peptone. These two reference materials are passed at the beginning and at the end of the analytical cycle, and after running the analysis of 20 samples. All results were expressed 
under the notation $\delta$ relative to Vienna PeeDee Belemnite and atmospheric nitrogen for $\delta^{13} \mathrm{C}$ and $\delta^{15} \mathrm{~N}$, respectively, according to the following equation (Peterson and Fry, 1987):

$$
\delta X=\left[\left(\frac{R_{\text {sample }}}{R_{\text {standard }}}\right)-1\right] \times 10^{3}
$$

where $X$ is $\delta^{13} \mathrm{C}$ or $\delta^{15} \mathrm{~N}$, and $\mathrm{R}$ is the isotopic ratio ${ }^{13} \mathrm{C} /{ }^{12} \mathrm{C}$ or ${ }^{15} \mathrm{~N} /{ }^{14} \mathrm{~N}$, respectively. Replicate measurements of reference materials (caffeine: USGS61 and USGS62) indicated that analytical errors were $<0.15 \%$ for both $\delta^{13} \mathrm{C}$ and $\delta^{15} \mathrm{~N}$. Percentages of elemental composition $\mathrm{C}$ and $\mathrm{N}$ were also obtained by the elemental analyzer, and calculated $\mathrm{C}: \mathrm{N}$ ratios were always below 3.5, which indicates a good efficiency of lipid removal (Table 1).

\subsection{Data analysis}

Shapiro-Wilk and Levene tests were performed to evaluate the assumptions of parametric tests (normality and homogeneity of variance, respectively). Transformations were performed so that the data fulfilled these assumptions (logarithmic transformation for $\mathrm{THg}$ ), and nonparametric tests were performed when this was not possible $\left(\delta^{15} \mathrm{~N}\right.$ and $\left.\delta^{13} \mathrm{C}\right)$. A oneway ANOVA test followed by a Tukey post-hoc test was used to evaluate significant differences in $\mathrm{THg}$ concentrations between species.

A two-way ANOVA followed by a Tukey post-hoc test was used to evaluate significant differences in $\mathrm{THg}$ concentrations between tissues. A Kruskal-Wallis test followed by a nonparametric multiple comparison post-hoc test was used to evaluate significant differences in $\delta^{13} \mathrm{C}$ and $\delta^{15} \mathrm{~N}$ values between shark species.

A Bayesian approach based on multivariate ellipse metrics (SIBER - Stable Isotope Bayesian Ellipses within the R-siar package; Jackson et al., 2011) was used to assess the overlapping of isotopic niche between species. This analysis generates areas of standard ellipses corrected for small sample sizes (SEAc) that correspond to $40 \%$ of the data regardless of the sample size (Batschelet, 1981), which can be compared between species and thus determine differences in the central isotope niche space and the niche superposition (Jackson et al., 2011). The calculation of standard ellipses (SEAc) was performed for the data $\delta 13 \mathrm{C}$ $\delta^{15} \mathrm{~N}, \delta^{13} \mathrm{C}-\mathrm{THg}$, and $\delta^{15} \mathrm{~N}-\mathrm{THg}$, supported by its associated covariance matrix: 


$$
\sum=\left[\begin{array}{cc}
\sigma_{x}^{2} & \operatorname{cov}(x, y) \\
\operatorname{cov}(y, x) & \sigma_{y}^{2}
\end{array}\right]
$$

which defines the shape and size of the ellipses, and the averages of $x$ and $y$ define the location of the ellipse on the graph (Jackson et al., 2011). To know the degree of niche overlapping, that is, the overlap in the areas of the standard ellipses (SEAc) of the species for each combination of the above parameters, was used the OVERLAP command. This overlap value normally ranges between 0 and 1 , and values closer to 1 represent greater overlap. The degree of overlapping was later transformed into percentages for a better visualization of the data (Jackson et al., 2011).

Finally, a nonparametric Spearman correlation test was performed to evaluate relationships between $\delta^{13} \mathrm{C}-\delta^{15} \mathrm{~N}, \delta^{13} \mathrm{C}-\mathrm{THg}$, and $\delta^{15} \mathrm{~N}-\mathrm{THg}$ values. All data analyses were performed using the program $\mathrm{R} 1.1 .423$

(R Development Core Team, 2014).

\section{Results}

\subsection{THg concentrations in shark fins and muscles}

A total of 175 shark samples (130 fins and 45 muscles) were analysed. THg concentrations were measured in all samples (Table 1). Fin THg concentrations were measured in all species, showing significant differences between species $(\mathrm{F}=5.55, \mathrm{df}=6, \mathrm{p}<0.05$; Table 1, Fig. 2), of which S. lewini showed the highest values $\left(88.56 \pm 82.30 \mathrm{ng} \mathrm{g}^{-1} \mathrm{ww}\right)$. Muscle $\mathrm{THg}$ concentrations were only measured in A. pelagicus and S. lewini (Fig. 3). S. lewini also showed the highest concentrations (809.29 $\pm 728.88 \mathrm{ng} \mathrm{g}^{-1} \mathrm{ww}$; Table 1, Fig. 3). These concentrations were significantly higher than fin $\mathrm{THg}$ concentrations for both species $(\mathrm{F}=$ 114.83, df $=1, \mathrm{p}<0.05$, Fig. 3).

\subsection{Risk assessment for consumption}


Average THg concentrations were compared with the maximum permitted level (ML) of $\mathrm{THg}$ in predatory fish recommended by the FAO/WHO of $1000 \mathrm{ng} \mathrm{g}^{-1}$ ww (FAO/WHO, 2011). THg fin concentrations were all below to ML (Figs. 2 and 3), and only for THg muscle concentrations some individuals of A. pelagicus and S. lewini exceeded the ML by two to almost three orders of magnitude (maximum values of 1893.46 and $2664.66 \mathrm{ng} \mathrm{g}^{-1} \mathrm{ww}$, respectively; Fig. 3).

The minimum, maximum, and average values of the estimated weekly intake (EWI) and the average Target Hazard Quotient (THQ) values were calculated for two age-specific human categories (adults and children). EWI results in fins were below the PTWI for all species (Table 2). However, EWI results in muscles for A. pelagicus and S. lewini exceeded this limit for both age-groups, except for A. pelagicus in adults, which presented a relatively high average but below to the recommended limit (2.21 $\mathrm{ng} \mathrm{g}^{-1} \mathrm{bw}$; Table 2). THQ results in fins for both age groups analyzed were $<1$ while THQ results in muscles of A. pelagicus and $S$. lewini were $>1$ for both age-groups (Table 2).

\subsection{Trophic interactions}

Only fins were analyzed for all seven shark species for ecological niche overlapping. An overlapping of $\delta^{13} \mathrm{C}-\delta^{15} \mathrm{~N}$ ellipses among all species was observed, some of them with a greater percentage of overlapping than others (Table 3, Figs. 4A and 5A). Particularly, $S$. tiburo showed the lowest percentage of shared niche with other species (Table 3, Fig. 5A), while A. pelagicus and S. lewini showed the highest one (Table 3, Fig. 5A).

Results in standard ellipses of $\delta^{13} \mathrm{C}-\mathrm{THg}$ and $\delta^{15} \mathrm{~N}-\mathrm{THg}$ (Tables 4 and 5, SEAc: Figs. 5B-C), showed for the genus Mustelus an important niche segregation in relation to other genera; particularly $M$. henlei showed lower percentages for $\delta^{13} \mathrm{C}-\mathrm{THg}$ and $S$. tiburo and M. henlei for $\delta^{15} \mathrm{~N}-\mathrm{THg}$ (Tables 4 and 5, Fig. 5B in purple, Fig. 5C in dark blue and purple). Conversely, most of the species showed a considerable niche overlap for these results (Figs. 5B-C), in which M. lunulatus and S. corona presented the highest percentage values for $\delta^{13} \mathrm{C}-\mathrm{THg}$ and M. lunulatus the highest values for $\delta^{15} \mathrm{~N}-\mathrm{THg}$ (Tables 4 and 5, Fig. 5B in neon green and neon blue, Fig. 5C in neon green). Likewise, for both $\delta^{13} \mathrm{C}-\mathrm{THg}$ and $\delta^{15} \mathrm{~N}-\mathrm{THg}$, S. lewini showed the largest ellipse area (229.45 and 168.14 , in $\% 0^{2}$, respectively), while M. lunulatus 
showed the smallest ellipse area (13.52 and 15.26, in $\%{ }^{2}$, respectively, Supplementary Table S2).

\subsection{Relationship between $\delta^{13} \mathrm{C}, \delta^{15} \mathrm{~N}$ and THg concentrations}

Fins values of $\delta^{15} \mathrm{~N}$ and $\delta^{13} \mathrm{C}$ varied significantly among species (Kruskal-Wallis, $\mathrm{X}^{2}=77.60$,

$\mathrm{df}=6, \mathrm{p}<0.05$ and $\mathrm{X}^{2}=37.46, \mathrm{df}=6, \mathrm{p}<0.05$, respectively), but not varied significantly for THg concentrations. Spearman correlation tests were performed separately for fins and muscles since significant differences were encountered in $\mathrm{THg}$ concentrations between fins and muscles. In fins, no significant $(\mathrm{p}>0.05)$ correlations were found between $\delta^{13} \mathrm{C}, \delta^{15} \mathrm{~N}$, and $\mathrm{THg}$, when all species were considered. At species level with fin samples, only a significant positive correlation was found between $\delta^{15} \mathrm{~N}$ - THg for S. tiburo (Spearman: $\mathrm{r}=$ $0.60, p=0.01)$. In muscles, no significant ( $p>0.05$ ) correlations were found between $\delta 13 \mathrm{C}$, $\delta^{15} \mathrm{~N}$, and $\mathrm{THg}$, whether considering both species together or species individually.

\section{Discussion}

This is the first study that reports $\mathrm{THg}$ contamination levels for some of the most representative shark species on the Colombian Pacific, and that describes ecological aspects associated with their trophic ecology, and the partition of ecological and foraging niches. This information can be of great help for the implementation of future conservation plans and strategies to reduce the trade and export of shark fin in Colombia and other neighboring countries.

\subsection{Levels of THg concentrations}

In the Colombian Pacific, sharks showed moderate THg concentrations in comparison to other studies worldwide (Table 6) likely related to tissue samples being from juvenile sharks (see discussion Section 4.3). In muscles, these concentrations were similar to $\mathrm{THg}$ measurements reported for several shark species in the Pacific coast of Costa Rica, in the Mexican Pacific coast, in the Southeastern United States Caribbean coast, and in the 
Southwest Indian Ocean (Maz-Courrau et al., 2012; Bergés-Tiznado et al., 2015; Kiszka et al., 2015; Sandoval-Herrera et al., 2016; O’Bryhim et al., 2017) (Table 6).

Differences in THg concentrations between fins and muscles could be explained by the high affinity that has THg with the thiol sulfuric groups present in the amino acids of muscles, showing high values for this tissue (Escobar-Sanchez et al., 2010; Pethybridge et al., 2010; O’Bryhim et al., 2017). However, fins also showed significant high $\mathrm{THg}$ concentrations for A. pelagicus and S. lewini, both species threatened according to the IUCN because of finning (Endangered and Critically Endangered, respectively; Rigby et al., 2019a, 2019b), which concerns about health status of these species.

\subsection{Effects on human health due to Hg overload and risk assessment}

According to FAO/WHO, the THg permitted concentration limit for humans is $1000 \mathrm{ng} \mathrm{g}^{-1}$ ww (FAO/WHO, 2011). Our data showed THg concentrations in fins and muscles below this limit (46.12 and $688.04 \mathrm{ng} \mathrm{g}^{-1} \mathrm{ww}$ on average, respectively). However, our results showed that muscles of some individuals of A. pelagicus and S. lewini presented THg concentrations that exceeded this safety limit for consumption.

EWI and THQ risk indexes for muscles of A. pelagicus and S. lewini also showed a risk for human health due to THg consumption in both adults and children. Particularly, the risks for children are greater because they consume three to four times more food in proportion to their body size than adults and, therefore, ingest larger amounts of chemicals per unit of body mass (United States Environmental Protection Agency (USEPA), 2008). However, since the fish ingestion rate in Colombia is unknown, it is possible the fish ingestion rate used is underestimated for the Colombian fishing community, and therefore, more specific studies including local fish and especially shark consumption should be carried out in the future. Although fins are exported to external markets, muscles can be consumed by adults and children of local communities of the Colombian Pacific (Fuentes-Gandara et al., 2016). THg released into the environment by both natural and anthropogenic origins, this last one increased rapidly in Colombia due to gold mining during the last decade (Güiza and Aristizabal, 2013), accentuates a public health problem. Therefore, and following guidelines of European Commission and FAO/WHO, we suggest that daily consumption of A. pelagicus 
and S. lewini is not safe for human health and should be regulated especially for children (Falco et al., 2006). These findings have also conservation implications, because A. pelagicus and $S$. lewini have been reported as the most exploited species in the Colombian Pacific coast (Caballero et al., 2012).

\subsection{Amplitude and overlapping patterns of ecological niche}

Regarding the amplitude and overlapping patterns, only fin samples were considered since this tissue has been already employed in stable isotope and fatty acid analyzes in sharks (Every et al., 2016; Rangel et al., 2019), revealing feeding habits and habitat use over periods of time of more than a year due to its slow turn-over rate (Malpica-Cruz et al., 2012). Niche overlap of all species is not $100 \%$ in terms of trophic level $\left(\delta^{15} \mathrm{~N}\right)$. It was possible to identify three groups in which the first was $M$. henlei with the highest average of $\delta^{15} \mathrm{~N}$, the second was $S$. tiburo with the lowest average of $\delta^{15} \mathrm{~N}$, and the third group was the rest of the species that had a high overlap in terms of $\delta^{15} \mathrm{~N}$ (A. pelagicus, C. cerdale, M. lunulatus, S. corona, and S. lewini). The first group seems to have prey of relatively higher trophic level, while the second group appears to have prey of relatively lower trophic level, even though generally the $\delta^{15} \mathrm{~N}$ results are low for all the individuals. Previous studies on the diet of M. henlei and S. tiburo indicate that these species feed both on small fishes and crustaceans, which could explain these results (Cortés et al., 1996; Pérez-Jiménez et al., 2016a, 2016b).

$\delta^{13} \mathrm{C}$ values in fins ranged between -15.64 and $-14.83 \%$. Although values for all the species were similar even for standard ellipses of $\delta^{13} \mathrm{C}$ and $\mathrm{THg}$, we suggest the existence of two shark groups in terms of habitat use. One group was only represented by $S$. tiburo (mean = $15.64 \%$ ) while remaining species formed the other group (range $=-15.50$ and $-14.62 \%$ ). $\delta^{13} \mathrm{C}$ values of shark species in this study were relatively high, indicating coastal habits (Hussey et al., 2011), with the exception of $S$. tiburo that showed a wide range of $\delta^{13} \mathrm{C}$ values, suggesting a wider foraging area. This result differs from other studies for most shark species analyzed here, such as S. lewini, which usually inhabits pelagic zones when they are adults, for their development, growth, and foraging (Compagno, 1984; Estupiñan-Montaño et al., 2009, 2017, 2021). Because the Colombian Pacific mangroves are known as suitable areas for shark species during their first years (Quintanilla et al., 2015) and considering the 
relatively low $\delta^{15} \mathrm{~N}$ results, these results reinforce also the hypothesis that the $S$. lewini specimens analyzed in this study were juveniles feeding in coastal habitats.

Overall, $\delta^{13} \mathrm{C}$ results suggest also a niche overlap in coastal areas for all the studied individuals, which could lead to a competition for food between these species. However, the significant differences found in isotopic relationships between $\delta^{15} \mathrm{~N}$ and $\mathrm{THg}$, suggests diet differences among individuals analyzed (Maya Meneses et al., 2016). For instance, S. lewini prefers cephalopods, while M. lunulatus consumes more stomatopods (Estupiñan-Montaño et al., 2009; Galvan-Magaña et al., 2013). These diet differences could thus allow coexistence of species in coastal areas, as has been reported for several shark species (Maya Meneses et al., 2016), even in other Colombian areas such as Malpelo Island (Estupiñan-Montaño et al., 2017). These results are also supported by SIBER-based analyses of the standard ellipses between $\delta^{13} \mathrm{C}$ and $\delta^{15} \mathrm{~N}$ (with the exception of $S$. tiburo, see Fig. 5A).

\subsection{Shark ecological patterns: implications for conservation}

This study was limited by the origin of the samples, since they correspond to seizures, in which most of them were only fins already cut off from the sharks, which makes it impossible to know other important biological variables such as size. However, isotopic data showed insights about age of individuals analyzed in this study. The generally low $\delta^{15} \mathrm{~N}$ results suggest that individuals analyzed in this study could be juveniles (Estupiñan-Montaño et al., 2009; Torres-Rojas et al., 2006). Considering both, relatively low $\delta^{15} \mathrm{~N}$ and relatively high $\delta^{13} \mathrm{C}$ values, these results reinforce also the hypothesis that most specimens analyzed in this study were juveniles feeding in coastal habitats.

Our findings suggest therefore two worrisome hypotheses: 1) most individuals collected, particularly A. pelagicus and S. lewini, were juveniles, and 2) biggest Colombian sharks fishing activity is concentrated in coastal areas. However, Payan et al. (2008) identified the pelagic zone as the most visited by the fishing fleet in the Colombian Pacific, where there is a greater incidental capture of elasmobranchs. Nevertheless, our findings suggest the potential shark fishing in coastal areas, likely in a small scale. The possibility of fishing coastal young Chondrichthyes or adults during their reproductive period should be considered as an important issue for fisheries management in Colombia and probably other 
neighboring countries with similar practices (Quintanilla et al., 2015), in order to maintain the population growth of these species that are in some state of threat. Particularly in the Colombian Pacific, a marine connectivity has been detected for adults and neonates of $S$. lewini between oceanic and coastal waters in Malpelo Island and the Sanquianga National Natural Park, respectively (Quintanilla et al., 2015; Estupiñan-Montaño et al., 2021). Therefore, potential extension of Marine Protected Areas mainly in coastal areas, or the inclusion of marine corridors between coastal and oceanic areas should be considered as an important measure to protect sharks in Colombia (Estupiñan-Montaño et al., 2021).

Survival of juveniles is particularly important for shark conservation (Cortés, 2002). Sharks are highly vulnerable to increased mortality rates due to their slow growth, late age of sexual maturation, low reproduction rate, and an important parental investment in young pups (Ferretti et al., 2008). Juveniles are generally segregated from adults in coastal waters as breeding areas, a strategy that is supposed to improve survival by providing shelter from predation and prey abundance (Heupel et al., 2007). However, these areas, which are generally found in estuarine and mangroves ecosystems (Nakano and Stevens, 2008), are the most affected in Colombia by THg contamination due to anthropogenic activities, as has been reported, in South Baja California (Mexico) (Maz-Courrau et al., 2012). This coastal contamination could also affect adult sharks during pregnancy period because it has been reported that females are capable of carrying out excretion processes by transferring part of their bioaccumulated THg to their embryos (Cadena-Cardenas, 2004; Pethybridge et al., 2010; Man et al., 2014). These situations may be happening in the Colombian Pacific coast. Species such as S. lewini are mobile and migrate in periods of rain constantly through the East Tropical Pacific Corridor between the islands of Cocos, Galapagos, and Malpelo (Bessudo et al., 2011). Since this corridor is a marine-protected area (MPA), it is possible that this regional conservation efforts carried out would be threatened by this $\mathrm{THg}$ contamination, in addition to coastal overfishing of juveniles and/or adults during their reproductive period. Further studies are needed to continue monitoring the $\mathrm{THg}$ exposure in sharks and local communities along the Colombian Pacific coast, as well as effective management of shark fishing in coastal areas, in order to guarantee their conservation in the long term. 


\section{Conclusions and recommendations}

This study contributed to assess the status of $\mathrm{THg}$ contamination of shark populations, and knowledge of the trophic ecology of A. pelagicus, C. cerdale, M. henlei, M. lunulatus, $S$. corona, S. lewini, and S. tiburo in the Colombian Pacific. Overall, it was found that $\mathrm{THg}$ concentrations vary according to the species and were moderate, in comparison to other studies. However, ML, EWI, and THQ results suggested human health risks to shark consumption, which is a warning signal for consumers, especially for children and pregnant women. In addition, isotope analyses results suggested that coastal areas have the highest capture of sharks, which would be affecting the growth of shark populations. This information helps to understand the role of these shark species that are the most affected by overfishing and finning in this area of the country, with the aim of providing useful information to develop management and conservation plans for these species. Furthermore, the identification of key habitats like foraging areas can be also important evidence for ideal conservation and management policies such as potential extension of MPAs or creation of marine corridors.

It is recommended for future studies to include molecular analyses to complement the information obtained in this study such as sex identification, to assess if females accumulate higher $\mathrm{THg}$ concentrations than males, which could increase risks of $\mathrm{THg}$ transfer to the neonates (Cadena-Cardenas, 2004; Pethybridge et al., 2010; Man et al., 2014). Additionally, shark size information would help explain possible bioaccumulation processes (Delshad et al., 2012; Maz-Courrau et al., 2012; Man et al., 2014; Kim et al., 2016), since adult sharks tend to accumulate more THg in their tissues than juveniles (Escobar-Sanchez et al., 2011). THg levels found here are an important issue for shark conservation, so pollution management should be considered as one of the most important issues for future management plans in Colombia or at regional level. Finally, for future investigations, the exact geographical fishing points would help to identify the areas of greatest threat of overfishing and finning for sharks in the Colombian Pacific and therefore prioritize fishing management plans for these areas.

\section{Acknowledgements}


We appreciate support of C. Churlaud and M. Brault-Favrou from the Plateforme Analyses Elémentaires of the LIENSs laboratory for their support during THg analyses, and G. Guillou from the Plateforme Analyses Isotopiques of the LIENSs laboratory for running stable isotope analyses. Thanks to the CPER (Contrat de Projet Etat-Région) and the FEDER (Fonds Européen de Développement Régional) for funding the AMA, and the IRMS of LIENSs laboratory. We thank the Malpelo and Other Marine Ecosystems Foundation, the Unit of National Natural Parks of Colombia and Fondo Patrimonial Fundación Malpelo for their support in collecting and providing the samples. The Corporation Center of Excellence in Marine Sciences - CEMarin also supported this study (DCBB, 2018). Special thanks to Andrea Paz for her essential help with the statistical analyses using the R platform. The IUF (Institut Universitaire de France) is acknowledged for its support to P. Bustamante as a Senior Member, and the Colombian Sciences Ministry for granting a Postdoctoral Fellowship to D. Barragán through the Francisco José de Caldas Fund (Call No 848 of 2019).

\section{References}

Adams, D.H., McMichael, R.H., 1999. Mercury levels in four species of sharks from the Atlantic coast of Florida. Fish. Bull. 97, 372-379.

Angel-Romero P.A., Barragán-Barrera D.C., Botero-Acosta N., Riet-Sapriza F., Caballero S. and Luna-Acosta A., 2018. Mercury Concentrations in Wild Humpback Whales (Megaptera novaeangliae) Sampled in the Colombian Pacific and the Antarctic Peninsula. Int. Whal. Comm, (SC/67b/E/09).

Aubail, A., Méndez-Fernandez, P., Bustamante, P., Churlaud, C., Ferreira, M., Vingada, J. V., Caurant, F., 2013. Use of skin and blubber tissues of small cetaceans to assess the trace element content of internal organs. Mar. Pollut. Bull. 76, 158-169.

Barragán-Barrera, D. C.; Luna-Acosta, A.; May-Collado, L. J.; Polo-Silva, C.; RietSapriza, F. G.; Bustamante, P.; Hernández-Ávila, M. P.; Vélez, N.; FaríasCurtidor, N. \& Caballero, S., 2019. Foraging habits and levels of mercury in a resident population of bottlenose dolphins (Tursiops truncatus) in Bocas del Toro Archipelago, Caribbean Sea, Panama. Marine Pollution Bulletin. 145: 343-356.

Batschelet, E., 1981. Circular Statistics in Biology. Academic Press, London.

Bergés-Tiznado, M.E., Marquez-Farías, F., Lara-Mendoza, R.E., Torres-Rojas, Y.E., Galvan-Magaña, F., BojorquezLeyva, H., Paez-Osuna, F., 2015. Mercury and selenium in muscle and target organs of scalloped hammerhead sharks (Sphyrna lewini) of the Gulf of California: dietary intake, molar ratios, loads, and human health risks. Arch. Environ. Contam. Toxicol. 69, 440-452.

Bessudo, S., Soler, G.A., Klimley, A.P., Ketchum, J.T., Hearn, A., Arauz, R., 2011. Residency of the scalloped hammerhead shark (Sphyrna lewini) at Malpelo Island and evidence of migration to other islands in the Eastern Tropical Pacific. Environ. Biol. Fishes 91, 165-176.

Bloom, N.S., 1992. On the chemical form of mercury in edible fish and marine invertebrate tissue. Can. J. Fish. Aquat. Sci. 49, 1010-1017.

Caballero, S., Cardeñosa, D., Soler, G., Hyde, J., 2012. Application of multiplex PCR approaches for shark molecular identification: Feasibility and applications for fisheries management and conservation in the Eastern Tropical Pacific. Mol. Ecol. Resour. 12, 233-237.

Cadena-Cárdenas, L., 2004. Mercurio total en peces elasmobranquios y teleósteos del Golfo de California. Master's Thesis, Instituto Tecnológico del Mar.

Caldas Aristizábal, J.P., Castro-González, E., Puentes, V., Rueda, M., Lasso, C., Duarte, L.O., Grijalba-Bendeck, M., Gómez, F., Navia López, A.F., Mejía-Falla, P.A., Bessudo, S., Diazgranados, M.C., Zapata Padilla, L.A., 2010. Plan de Acción Nacional para la Conservación y Manejo de Tiburones, Rayas y Quimeras de Colombia (PANTiburones Colombia).

Castañeda S.D. \& Sandoval S.A., 2007. Hábitos alimentarios del tiburón martillo Sphyrna lewini (Griffith \& Smith, 1834) en el Pacifico ecuatoriano. En: Martínez-Ortíz J \& F Galván- Magaña (eds). Tiburones en el Ecuador: Casos de estudio / Sharks in Ecuador: Case studies, pp. 66-76. EPESPO - PMRC, Manta.

Castellanos, A., Chaparro-Narvaez, P., Morales-Plaza, C.D., Alzate, A., Padilla, J., Arevalo, M., Herrera, S., 2016. Malaria in gold-mining areas in Colombia. Mem. Inst. Oswaldo Cruz 111, 59-66. 
Chouvelon, T., Spitz, J., Caurant, F., Mèndez-Fernandez, P., Autier, J., Lassus-Débat, A., Chappuis, A., Bustamante, P., 2012. Enhanced bioaccumulation of mercury in deep-sea fauna from the Bay of Biscay (north-east Atlantic) in relation to trophic positions identified by analysis of carbon and nitrogen stable isotopes. Deep. Res. Part I Oceanogr. Res. Pap. 65, 113-124.

Clarke, S.C., McAllister, M.K., Michielsens, G.J., 2004. Estimates of shark species composition and Numbers associated with the shark fin trade based on Hong Kong auction data. J. Northwest Atl. Fish. Sci. 35, $453-465$.

Clarke, S.C., Milner-Guilland, E.J., Bjorndal, T., 2007. Social, Economic, and Regulatory Drivers of the Shark Fin Trade. Mar. Resour. Econ. 22, 305-327.

Compagno, L.J.V., 1984. FAO species catalogue. Vol. 4. Sharks of the world. An annotation and illustrated catalogue of shark species known to date. FAO Fish. Synopsis., 4(125) Pt. 1, 249.

Cortés, E., Manire, C.A., Hueter, R.E., 1996. Diet, feeding habits and diet feeding chronology of the bonnethead shark, Sphyrna tiburo, in southwest Florida. Bull Mar Sci 58, 353-367.

Cortés E., 2002. Incorporating uncertainty into demographic modelling: application to shark populations and their conservation. Conservation Biology 18, 1048-1062.

Cortés, E., Lowry, D., Bethea, D. \& Lowe, C.G., 2016. Sphyrna tiburo. The IUCN Red List of Threatened Species 2016: e.T39387A2921446.

Cresson, P., Bouchoucha, M., Morat, F., Miralles, F., Chavanon, F., Loizeau, V., Cossa, D., 2015. A multitracer approach to assess the spatial contamination pattern of hake (Merluccius merluccius) in the French Mediterranean. Sci. Total Environ. 532, 184-194.

Delshad, S.T., Mousavi, S.A., Islami, H. rajabi, Pazira, A., 2012. Mercury concentration of the whitecheek shark, Carcharhinus dussumieri (elasmobranchii, chondrichthyes), and its relation with length and sex. Panam. J. Aquat. Sci. 7, 135-142.

DeNiro, M.J., Epstein, S., 1977. Mechanism of carbon fractionation associated with lipid synthesis. Science 197, 261263.

Dulvy, N.K., Fowler, S.L., Musick, J.A., Cavanagh, R.D., Kyne, P.M., Harrison, L.R., Carlson, J.K., Davidson, L.N. k, Fordham, S. V., Francis, M.P., Pollock, C.M., Simpfendorfer, C.A., Burgess, G.H., Carpenter, K.E., Compagno, L.J. v, Ebert, D.A., Gibson, C., Heupel, M.R., Livingstone, S.R., Sanciangco, J.C., Stevens, J.D., Valenti, S., White, W.T., 2014. Extinction risk and conservation of the world's sharks and rays. Elife 3, e00590.

Environmental Protection Agency, 2011. Exposure Factors Handbook, 2011 edition. Office of Research and Development, United States Environmental Protection Agency, Washington, D.C.

Eriksson, H., Clarke, S., 2015. Chinese market responses to overexploitation of sharks and sea cucumbers. Bio Conserv. 184, 163-173.

Escobar-Sánchez, O., Galván-Magaña, F., Rosíles-Martínez, R., 2010. Mercury and selenium bioaccumulation in the smooth hammerhead shark, Sphyrna zygaena linnaeus, from the Mexican Pacific Ocean. Bull. Environ. Contam. Toxicol. 84, 488-491.

Escobar-Sánchez, O., Galván-Magaña, F., Rosíles-Martínez, R., 2011. Biomagnification of mercury and selenium in blue shark Prionace glauca from the Pacific Ocean off Mexico. Biol. Trace Elem. Res. 144, 550-559.

Estupiñán-Montaño, C., Cedeño-Figueroa, L.G., Galván-Magaña, F., 2009. Hábitos alimentarios del tiburón martillo Sphyrna lewini (Griffith \& Smith, 1834) (Chondrichthyes) en el Pacífico ecuatoriano. Rev. Biol. Mar. Oceanogr. 44, 379-386.

Estupiñán-Montaño, C., Galván-Magaña, F., Tamburín, E., Sánchez-González, A., Villalobos-Ramírez, D.J., MurilloBohórquez, N., Bessudo-Lion, S., Estupiñán-Ortiz, J.F., 2017. Trophic inference in two sympatric sharks. 47, 357-364.

Estupiñán-Montaño, C., Tamburin, E., Delgado-Huertas, A., 2021. Stable isotope evidence for movements of hammerhead sharks Sphyrna lewini, connecting two natural protected areas in the Colombian Pacific. Mar. Biodivers. 51 (5), 1-8.

Every, S.L., Pethybridge, H.R., Crook, D.A., Kyne, P.M., Fulton, C.J., 2016. Comparison of fin and muscle tissues for analysis of signature fatty acids in tropical euryhaline sharks. J. Exp. Mar. Biol. Ecol. 479, 46-53.

Fabinyi, M., Liu, N., 2014. Seafood banquets in Beijing: Consumer perspectives and implications for environmental sustainability, Conservancy. Soc. 1-38.

FAO/WHO, 2011. Working document for information and use in discussions related to contaminants and toxins in the GSCTFF. Joint FAO/WHO Food Standards Program. Codex committee on contaminants in foods Fifth Session. The Hague, The Netherlands, 21-25 March 2011.

Falcó, G., Llobet, J.M., Bocio, A., Domingo, J.L., 2006. Daily intake of arsenic, cadmium, mercury, and lead by consumption of edible marine species. J. Agric. Food Chem. 54, 6106-6112. 
Ferretti, F., Myers, R.A., Serena, F., Lotze, H.K., 2008. Loss of large predatory sharks from the Mediterranean Sea. Conserv. Biol. 22, 952-964.

Fisk, A.T., Tittlemier, S.A., Pranschke, J.L., Norstrom, R.J., 2002. Using anthropogenic contaminants and stable isotopes to assess the feeding ecology of Greenland sharks. Ecology. 83, 2162-2172.

Fontaine, M., Carravieri, A., Simon-Bouhet, B., Bustamante, P., Gasco, N., Bailleul, F., Guinet, C., Cherel, Y., 2015. Ecological tracers and at-sea observations document the foraging ecology of southern long-finned pilot whales (Globicephala melas edwardii) in Kerguelen waters. Mar. Biol. 162, 207-219.

Food and Agriculture Organization (FAO), 2009. The State of World Fisheries and Aquaculture 2008. 2009 ed. Food and Agriculture Organization of the United Nations, Rome.

Fuentes-Gandara, F., Pinedo-Hernández, J., Marrugo-Negrete, J., Díez, S., 2016. Human health impacts of exposure to metals through extreme consumption of fish from the Colombian Caribbean Sea. Environ. Geochem. Health 40, 229-242.

Galván-Magaña, F., Polo-Silva, C., Hernández-Aguilar, S.B., Sandoval-Londoño, A., Ochoa-Díaz, M.R., AguilarCastro, N., Castañeda-Suárez, D., Cabrera Chavez-Costa, A., Baigorrí-Santacruz, A., Torres-Rojas, Y.E., Abitia-Cárdenas, L.A., 2013. Shark predation on cephalopods in the Mexican and Ecuadorian Pacific Ocean. Deep Sea Res. II Top. Stud. Oceanogr. 95, 52-62.

Garcia Barcia, L., Argiro, J., Babcock, E. A., Cai, Y., Shea, S. K. H., \& Chapman, D. D., 2020. Mercury and arsenic in processed fins from nine of the most traded shark species in the Hong Kong and China dried seafood markets: The potential health risks of shark fin soup. Marine Pollution Bulletin, 157.

Güiza, L., Aristizábal, J.D., 2013. Mercury and gold mining in Colombia: A failed state. Universitas Scientiarum. 18(1), 33-49.

Helfman, G., Burgess, G., 2014. Sharks: The Animal Answer Guide [e-book]. Baltimore: Johns Hopkins University Press. Available from: eBook Collection (EBSCOhost), Ipswich, MA., 47.

Hernández Betancourt, S., Serrano Flores, F., Chumba Segura, L., Sélem Salas, C.I., Santos, J.C., 2011. Los tiburones en la costa norte de Yucatán : ¿ Poblaciones amenazadas por la sobrepesca ? Bioagrociencias Tópicos de Interés. 4, 39-42.

Heupel, M.R., Carlson, J.K., Simpfendirfer, C.A., 2007. Shark nursery areas: concepts, definition, characterization and assumptions. Marine Ecology Pro- gress Series. 337:287-297.

Hislop, J.R.G., Harris, M.P., Smith, J.G.M., 1991. Variation in the calorific value and total energy content of the lesser sandeel (Ammodytes marinus) and other fish preyed on by seabirds. J. Zool. 224, 501-517.

Hussey, N.E., Chapman, D.D., Donnelly, E., Abercrombie, D.L., Fisk, A.T., 2011. Fin-icky samples: an assessment of shark fin as a source material for stable isotope analysis. Limnol. Oceanogr. Methods 9, 524-532.

Jackson, A.L., Inger, R., Parnell, A.C., Bearhop, S., 2011. Comparing isotopic niche widths among and within communities: SIBER - Stable Isotope Bayesian Ellipses in R. J. Anim. Ecol. 80, 595-602.

Jaiteh, V.F., Loneragan, N.R., Warren, C., 2017. The end of shark finning? Impacts of declining catches and fin demand on coastal community livelihoods. Mar. Policy 82, 224-233.

JECFA, 2004. Methylmercury. In: Safety evaluation of certain food additives and contaminants. Report of the 61st Joint FAO/WHO Expert Committee on Food Additives. Geneva, World Health Organization, International Programme on Chemical Safety. WHO Technical Report Series. 922,132-139.

Kim, S.J., Lee, H.K., Badejo, A.C., Lee, W.C., Moon, H.B., 2016. Species-specific accumulation of methyl and total mercury in sharks from offshore and coastal waters of Korea. Mar. Pollut. Bull. 102, 210-215.

Kiszka, J.J., Aubail, A., Hussey, N.E., Heithaus, M.R., Caurant, F., Bustamante, P., 2015. Plasticity of trophic interactions among sharks from the oceanic south-western Indian Ocean revealed by stable isotope and mercury analyses. Deep. Res. Part I Oceanogr. Res. Pap. 96, 49-58.

Le Bourg, B., Kiszka, J.J., Bustamante, P., Heithaus, M.R., Jaquemet, S., Humber, F., 2019. Effect of body length, trophic position and habitat use on mercury concentrations of sharks from contrasted ecosystems in the southwestern Indian Ocean. Environ. Res. 169, 387-395.

Le Croizier, G., Lorrain, A., Schaal, G., Ketchum, J., Hoyos-Padilla, M., Besnard, L., Munaron, J.-M., Le Loc, h, F., \& Point, D, 2020. Trophic resources and mercury exposure of two silvertip shark populations in the Northeast Pacific Ocean. Chemosphere, 253.

Leung, S., Chan, S., Lui, S., Lee, W., Davies, D., 2000. Growth and nutrition of Hong Kong children aged 0-7 years. The Journal of Paediatrics and Child Health. 36(1), 56-65.

Maggie, B., Covington, M.D., 2004. Omega-3 fatty acids. MMW Fortschr. Med. 153 (Suppl), 90-94.

Malpica-Cruz, L., Herzka, S.Z., Sosa-Nishizaki, O., Lazo, J.P., 2012. Tissue-specific isotope trophic discrimination factors and turnover rates in a marine elasmobranch: empirical and modeling results. Can. J. Fish. Aquat. Sci. $69,551-564$. 
Man, Y.B., Wu, S.C., Wong, M.H., 2014. Shark fin, a symbol of wealth and good fortune may pose health risks: the case of mercury. Environ. Geochem. Health 1-13.

Massé, F., McDermott, J., 2017. Responsible Business Conduct: Due Diligence in Colombia's Gold Supply Chain Gold Mining in Antioquia.

Matulik, A.G., Kerstetter, D.W., Hammerschlag, N., Divoll, T., Hammerschmidt, C.R., Evers, D.C., 2017. Bioaccumulation and biomagnification of mercury and methylmercury in four sympatric coastal sharks in a protected subtropical lagoon. Mar. Pollut. Bull. 116(1-2), 357-364.

Maya Meneses, C.I., Torres Rojas, Y.E., Galván Magaña, F., Aguiñiga García, S., Trasviña Carrillo, L.D., 2016. Trophic overlap between blue sharks (Prionace glauca) and shortfin makos (Isurus oxyrinchus): Trophic linkages between two shark species in the Eastern Pacific Ocean food web. Food Webs 7, 13-19.

Maz-Courrau, A., López-Vera, C., Galván-Magaña, F., Escobar-Sánchez, O., Rosíles-Martínez, R., Sanjuán-Muñoz, A., 2012. Bioaccumulation and biomagnification of total mercury in four exploited shark species in the Baja California Peninsula, Mexico. Bull. Environ. Contam. Toxicol. 88, 129-134.

McKinney, M.A., Dean, K., Hussey, N.E., Cliff, G., Wintner, S.P., Dudley, S.F.J., Zungu, M.P., Fisk, A.T., 2016. Global versus local causes and health implications of high mercury concentrations in sharks from the east coast of South Africa. Sci. Total Environ. 541, 176-183.

Mohammed, A., Mohammed, T., 2017. Mercury, arsenic, cadmium and lead in two commercial shark species (Sphyrna lewini and Carcharinus porosus) in Trinidad and Tobago. Mar. Pollut. Bull. 119, 214-218.

Murray, J., Burt, J.R., 1969. The Composition of Fish (Torry Advisory Note No. 38). Torry Research Station.

Mycock, S.G., 2004. Sphyrna corona. The IUCN Red List of Threatened Species 2004: e.T44591A10910637.

Nadal, M., Ferré-Huget, N., Martí-Cid, R., Schuhmacher, M., Domingo, J.L., 2008. Exposure to metals through the consumption of fish and seafood by population living near the Ebro River in Catalonia, Spain: health risks. Human Ecol. Risk Assess. 14, 780-795.

Nakano, H., Stevens, J.D., 2008. The biology and ecology of the blue shark, Prionace glauca. In: Sharks of the Open Ocean (eds. M.D. Camhi, E.K. Pikitch, E.A. Babcock), Blackwell Publishing, Oxford, UK. 140-151.

Nalluri, D., Baumann, Z., Abercrombie, D.L., Chapman, D.D., Hammerschmidt, C.R., Fisher, N.S., 2014. Methylmercury in dried shark fins and shark fin soup from American restaurants. Sci. Total Environ. 496, 644648.

Navia, A.F., Mejía-Falla, P.A., Salcedo-Reyes, J.C., 2016. Fishing effects on elasmobranchs from the Pacific Coast of Colombia. 21, 9-22.

O’Bryhim, J.R., Adams, D.H., Spaet, J.L.Y., Mills, G., Lance, S.L., 2017. Relationships of mercury concentrations across tissue types, muscle regions and fins for two shark species. Environ. Pollut. 223, 323-333.

Palacios-Torres, Y., Caballero-Gallardo, K., Olivero-Verbel, J., 2018. Mercury pollution by gold mining in a global biodiversity hotspot, the Choco biogeographic region, Colombia. Chemosphere. 193, 421-430.

Payan, L. F., Navia, A. F., Mejía-Falla, P. A., Ramírez, V., Gómez, L. S., Tobon, A., 2008. Caracterización y comportamiento histórico de la pesca de elasmobranquios en el Pacífico colombiano. Fundación SQUALUS, 32.

Payne, S.A., Johnson, B.A., Otto, R.S., 1999. Proximate composition of some north-eastern Pacific forage fish species. Fish. Oceanogr. 8, 159-177.

Pérez-Valbuena, G.J., 2007. Historia, geografía y puerto como determinantes de la situación social de Buenaventura. Del Pacífico Colombiano. 55-81.

Pérez-Jiménez, J., Carlisle, A.B., Chabot, C.L., Vásquez, V.E. \& Ebert, D.A., 2016. Mustelus henlei. The IUCN Red List of Threatened Species 2016: e.T161648A80672263.

Pérez-Jiménez, J., White, C.F., Ruiz, C., Carlisle, A.B. \& Lowe, C.G., 2016a. Mustelus lunulatus. The IUCN Red List of Threatened Species 2016: e.T161640A80672480.

Peterson, B.J., Fry, B.,1987. Stable Isotopes in Ecosystem Studies. Annual Review of Ecology and Systematics. 18, 293-320.

Pethybridge, H., Butler, E. C. V., Cossa, D., Daley, R., Boudou, A., 2012. Trophic structure and biomagnification of mercury in an assemblage of deepwater chondrichthyans from southeastern Australia. Marine Ecology Progress Series. 451, 163-174.

Pollom, R., Avalos, C., Bizzarro, J., Burgos-Vazquez, M.I., Cevallos, A., Espinoza, M., Herman, K., Gonzalez, A., Mejía-Falla, P.A., Morales-Saldaña, J.M., Navia, A.F., Pérez Jiménez, J.C., Sosa-Nishizaki, O., Velez-Zuazo, X., 2020. Carcharhinus cerdale. In: The IUCN Red List of Threatened Species 2020.

R Development Core Team, 2014. R: A Language and Environment for Statistical Computing. R Foundation for Statistical Computing, Vienna, Austria. 
Rangel, B.S., Hussey, N.E., Gomes, A.D., Rodrigues, A., Martinelli, L.A., Moreira, R.G., 2019. Resource partitioning between two young-of-year cownose rays Rhinoptera bonasus and $R$. brasiliensis within a communal nursery inferred by trophic biomarkers. J. Fish. Biol. 94, 781-788.

Rigby, C.L., Barreto, R., Carlson, J., Fernando, D., Fordham, S., Francis, M.P., Herman, K., Jabado, R.W., Liu, K.M., Marshall, A., Pacoureau, N., Romanov, E., Sherley, R.B. \& Winker, H., 2019. Alopias pelagicus. The IUCN Red List of Threatened Species 2019: e.T161597A68607857.

Rigby, C.L., Dulvy, N.K., Barreto, R., Carlson, J., Fernando, D., Fordham, S., Francis, M.P., Herman, K., Jabado, R.W., Liu, K.M., Marshall, A., Pacoureau, N., Romanov, E., Sherley, R.B. \& Winker, H., 2019a. Sphyrna lewini. The IUCN Red List of Threatened Species 2019: e.T39385A2918526.

Rodríguez Ortiz, S., Ibañez, A., Mantilla, N., 2016. La Pesca Ilegal Marina en Colombia. Procuraduría General de la Nacion - Fundacion MarViva. Bogot'a, Colombia, 34.

Ross Salazar, E., Valverde Salas, M., Posada, J.M., Díaz Merlano, J.M., Velandia, M., 2019. Comercio internacional de tiburones y rayas en Costa Rica, Panama y Colombia. Fundacion MarViva. San José, Costa Rica, 95.

Sandoval-Herrera, N.I., Vargas-Soto, J.S., Espinoza, M., Clarke, T.M., Fisk, A.T., Wehrtmann, I.S., 2016. Mercury levels in muscle tissue of four common elasmobranch species from the Pacific coast of Costa Rica, Central America. Reg. Stud. Mar. Sci. 3, 254-261.

Storelli, M.M., Giacominelli-Stuffer, R., Marcotrigiano, G.O., 2001. Total mercury and methylmercury in tuna fish and sharks from the South Adriatic Sea. Ital. J. Food Sci. 13 (1), 101-106.

Teffer, A.K., Staudinger, M.D., Taylor, D.L., Juanes, F., 2014. Trophic influences on mercury accumulation in top pelagic predators from offshore New England waters of the northwest Atlantic Ocean. Mar. Environ. Res. 101, 124-134.

The 8 restaurant., 2017. Grand Lisboa. Macau: Avenida de Lisboa.

Torres-Rojas, Y.E., Hernández, A., Galván, F., 2006. Feeding habits of the scalloped hammerhead Sphyrna lewini, in Mazatlán waters, southern Gulf of California, Mexico. Cybium. 30(4): 85-90.

Tubb, D., 2015. Muddy decisions: gold in the Chocó, Colombia. Extr. Ind. Soc. 2, 722-733.

United States Environmental Protection Agency (USEPA), 1989. Risk assessment guidance for superfund, Vol. I: Human Health Evaluation Manual. EPA/540/1-89/002. Office of Solid Waste and Emergency Response. Washington, DC, USA.

United States Environmental Protection Agency (USEPA), 2000. Guidance for assessing chemical contaminant, data for use in fish advisories. Vol. 1: fish sampling and analysis, third ed. EPA 823-R-95-007. Office of Water, Washington, DC, USA.

United States Environmental Protection Agency (USEPA), 2008. Child-Specific Exposure Factors Handbook (Final Report) 2008. EPA/600/R-06/096F. National Center for Environmental Assessment Office of Research and Development, Washington, DC.

United States Environmental Protection Agency (USEPA), 2010. Risk-Based Concentration Table.

Quintanilla, S., Gómez, A., Mariño-ramírez, C., Sorzano, C., Bessudo, S., Soler, G., Bernal, J.E., Caballero, S., 2015. Conservation Genetics of the Scalloped Hammerhead Shark in the Pacific Coast of Colombia. 448-458.

Vieira, C., Morais, S., Ramos, S., Delerue-Matos, C., Oliveira, M.B.P.P., 2011. Mercury, cadmium, lead and arsenic levels in three pelagic fish species from the Atlantic Ocean: Intra- and inter-specific variability and human health risks for consumption. Food Chem. Toxicol. 49, 923-932.

Whitcraft S., Hofford A., Hilton P., O’Malley M., Jaiteh M., Knights P., 2014. Evidence of Declines in Shark Fin Demand, China, WildAid, San Francisco, CA.

WHO, 2006. Exposure to Mercury: A major public health concern. Prev. Dis. Through Heal. Environ. 4.

World Gold Council, 2020. Gold Mine Production. Goldhub. https://www.gold.org/goldhub/data/historical-mineproduction. (Accessed 30 June 2020). 
Table 1. Total mercury ( $\mathrm{THg}$ in $\left.\mathrm{ng} \mathrm{g}^{-1} \mathrm{ww}\right)$ concentration, stable isotopes ratios $\left(\delta^{13} \mathrm{C}\right.$ and $\delta^{15} \mathrm{~N}$ in $\left.\% 0\right), \mathrm{C}$ and $\mathrm{N}$ ratio $(\mathrm{C}: \mathrm{N})$ in sharks of the Colombian Pacific. Means and standard deviations were calculated (Mean \pm SD). NA: data not available.

\begin{tabular}{|c|c|c|c|c|c|c|}
\hline Species & Tissue & $\mathrm{n}$ & $\begin{array}{c}\text { THg } \\
\text { Mean } \pm \text { SD }\end{array}$ & $\begin{array}{c}\delta^{15} \mathrm{~N} \\
\text { Mean } \pm \mathrm{SD}\end{array}$ & $\begin{array}{c}\delta^{13} \mathrm{C} \\
\text { Mean } \pm \text { SD }\end{array}$ & $\begin{array}{c}\mathrm{C}: \mathrm{N} \\
\text { Mean } \pm \mathrm{SD}\end{array}$ \\
\hline \multirow{2}{*}{ Alopias pelagicus } & Fins & 30 & $88.07 \pm 97.66$ & $13.05 \pm 0.56$ & $-15.14 \pm 0.74$ & $3.04 \pm 0.14$ \\
\hline & Muscles & 25 & $566.78 \pm 337.07$ & $14.19 \pm 0.52$ & $-16.99 \pm 0.60$ & $3.34 \pm 0.15$ \\
\hline \multirow{2}{*}{ Carcharhinus porost } & Fins & 9 & $45.56 \pm 25.40$ & $13.64 \pm 0.47$ & $-14.65 \pm 0.80$ & $2.81 \pm 0.72$ \\
\hline & Muscles & NA & NA & NA & NA & NA \\
\hline \multirow{2}{*}{ Mustelus henlei } & Fins & 25 & $23.45 \pm 15.27$ & $14.16 \pm 0.56$ & $-15.50 \pm 0.45$ & $3.08 \pm 0.38$ \\
\hline & Muscles & NA & NA & NA & NA & NA \\
\hline \multirow{2}{*}{ Mustelus lunulatus } & Fins & 20 & $18.38 \pm 11.76$ & $13.14 \pm 0.39$ & $-14.81 \pm 0.35$ & $2.52 \pm 0.72$ \\
\hline & Muscles & NA & NA & NA & NA & NA \\
\hline \multirow{2}{*}{ Sphyrna corona } & Fins & 10 & $24.10 \pm 16.16$ & $12.74 \pm 0.42$ & $-14.62 \pm 0.30$ & $3.09 \pm 0.07$ \\
\hline & Muscles & NA & NA & NA & NA & NA \\
\hline \multirow{3}{*}{ Sphyrna lewini } & Fins & 19 & $88.56 \pm 82.30$ & $13.61 \pm 0.63$ & $-14.83 \pm 0.88$ & $2.66 \pm 0.71$ \\
\hline & & & & & & \\
\hline & Muscles & 20 & $809.29 \pm 728.88$ & $15.46 \pm 0.67$ & $-16.09 \pm 0.85$ & $3.34 \pm 0.14$ \\
\hline \multirow{2}{*}{ Sphyrna tiburo } & Fins & 17 & $34.69 \pm 32.10$ & $12.31 \pm 0.56$ & $-15.64 \pm 0.96$ & $3.04 \pm 0.64$ \\
\hline & Muscles & NA & NA & NA & NA & NA \\
\hline
\end{tabular}


Table 2. Estimated weekly intake (EWI) and Target Hazard Quotient (THQ) for seven shark species of the Colombian Pacific. The provisional tolerable weekly intake (PTWI) recommended by the Joint FAO/WHO Expert Committee (2004) is $1.6 \mathrm{ng} \mathrm{g}^{-1}$ bw for children and $3.2 \mathrm{ng} \mathrm{g}^{-1}$ bw for adults. THQ values $>1$ indicate possible adverse effects for human health.

\begin{tabular}{|c|c|c|c|c|c|c|}
\hline Age group & Species & Tissue & $\begin{array}{c}\text { Mean EWI } \\
(\mu \mathrm{g} / \mathrm{kg})\end{array}$ & $\begin{array}{l}\text { Min EWI - } \\
\text { Max EWI } \\
(\mu \mathrm{g} / \mathrm{kg})\end{array}$ & Mean THQ & $\begin{array}{l}\text { Min THQ - } \\
\text { Max THQ }\end{array}$ \\
\hline \multirow{9}{*}{$\begin{array}{c}\text { Children } \\
\text { (1-19 years) } \\
30 \mathrm{~kg}\end{array}$} & \multirow{2}{*}{ A. pelagicus } & Fins & 0.11 & $0.01-0.68$ & 0.33 & $0.03-2.03$ \\
\hline & & Muscles & 3.78 & $0.13-12.62$ & 2.10 & $0.07-7.03$ \\
\hline & C. porosus & Fins & 0.06 & $0.02-0.13$ & 0.17 & $0.05-0.37$ \\
\hline & M. henlei & Fins & 0.03 & $0.01-0.09$ & 0.09 & $0.03-0.28$ \\
\hline & M. lunulatus & Fins & 0.02 & $0.01-0.07$ & 0.07 & $0.03-0.21$ \\
\hline & S. corona & Fins & 0.03 & $0.01-0.08$ & 0.09 & $0.04-0.24$ \\
\hline & \multirow{2}{*}{ S. lewini } & Fins & 0.11 & $0.02-0.40$ & 0.33 & $0.07-1.20$ \\
\hline & & Muscles & 5.40 & $0.30-17.76$ & 3.00 & $0.17-9.89$ \\
\hline & S. tiburo & Fins & 0.04 & $0.01-0.16$ & 0.13 & $0.02-0.47$ \\
\hline \multirow{9}{*}{$\begin{array}{c}\text { Adult } \\
\text { (25-65 years) } \\
60 \mathrm{~kg}\end{array}$} & \multirow{2}{*}{ A. pelagicus } & Fins & 0.06 & $0.00-0.34$ & 0.16 & $0.01-1.01$ \\
\hline & & Muscles & 2.57 & $0.09-8.58$ & 1.05 & $0.04-3.51$ \\
\hline & C. porosus & Fins & 0.03 & $0.01-0.06$ & 0.08 & $0.03-0.19$ \\
\hline & M. henlei & Fins & 0.01 & $0.00-0.05$ & 0.04 & $0.01-0.14$ \\
\hline & M. lunulatus & Fins & 0.01 & $0.01-0.04$ & 0.03 & $0.02-0.10$ \\
\hline & S. corona & Fins & 0.02 & $0.01-0.04$ & 0.04 & $0.02-0.12$ \\
\hline & \multirow{2}{*}{ S. lewini } & Fins & 0.06 & $0.01-0.20$ & 0.16 & $0.03-0.60$ \\
\hline & & Muscles & 3.67 & $0.21-12.08$ & 1.50 & $0.08-4.94$ \\
\hline & S. tiburo & Fins & 0.02 & $0.00-0.08$ & 0.06 & $0.01-0.24$ \\
\hline
\end{tabular}


Table 3. Overlapping percentage of corrected standard ellipses (SEAc) of $\delta^{13} \mathrm{C}$ and $\delta^{15} \mathrm{~N}$ in fins of seven shark species of the Colombian Pacific, including: Alopias pelagicus, Mustelus lunulatus, Sphyrna lewini, Sphyrna tiburo, Mustelus henlei, Carcharhinus porosus and Sphyrna corona.

\begin{tabular}{|c|c|c|c|c|c|c|c|}
\hline Species & A. pelagicus & M. lunulatus & S. lewini & S. tiburo & M. henlei & C. porosus & S. corona \\
\hline A. pelagicus & $*$ & 88.6 & 29.4 & 9.7 & 0.7 & 23.2 & 65.9 \\
\hline M. lunulatus & 31.4 & $*$ & 18.6 & 0.0 & 0.0 & 16.5 & 33.1 \\
\hline S. lewini & 42.3 & 75.2 & $*$ & 0.0 & 36.7 & 92.8 & 17.8 \\
\hline S. tiburo & 13.2 & 0.0 & 0.0 & $*$ & 0.0 & 0.0 & 9.7 \\
\hline M. henlei & 0.4 & 0.0 & 16.5 & 0.0 & $*$ & 6.6 & 0.0 \\
\hline C. porosus & 23.9 & 48.1 & 66.6 & 0.0 & 10.6 & $*$ & 1.1 \\
\hline S. corona & 21.7 & 30.8 & 4.1 & 2.3 & 0.0 & 0.3 & $*$ \\
\hline
\end{tabular}


Table 4. Percentage of overlap (in \%) of corrected standard ellipses (SEAc) of $\delta^{13} \mathrm{C} v s \mathrm{THg}$ for fins of seven shark species of the Colombian Pacific, including: Alopias pelagicus, Mustelus lunulatus, Sphyrna lewini, Sphyrna tiburo, Mustelus henlei, Carcharhinus porosus and Sphyrna corona.

\begin{tabular}{|c|c|c|c|c|c|c|c|}
\hline Species & A. pelagicus & M. lunulatus & S. lewini & S. tiburo & M. henlei & C. porosus & S. corona \\
\hline A. pelagicus & $*$ & 100.0 & 68.8 & 40.6 & 37.4 & 67.4 & 90.9 \\
\hline M. lunulatus & 6.5 & $*$ & 4.9 & 7.9 & 4.6 & 7.1 & 58.8 \\
\hline S. lewini & 76.0 & 83.8 & $*$ & 27.8 & 9.1 & 87.8 & 99.7 \\
\hline S. tiburo & 19.9 & 59.8 & 12.3 & $*$ & 100.0 & 41.3 & 30.2 \\
\hline M. henlei & 4.0 & 7.5 & 0.9 & 21.9 & $*$ & 12.0 & 0.0 \\
\hline C. porosus & 18.1 & 29.1 & 21.3 & 22.6 & 29.9 & $*$ & 42.1 \\
\hline S. corona & 6.6 & 65.9 & 6.6 & 4.5 & 0.0 & 11.5 & $*$ \\
\hline
\end{tabular}


Table 5. Percentage of overlap (in \%) of corrected standard ellipses (SEAc) of $\delta^{15} \mathrm{~N}$ vs THg for fins of seven shark species of the Colombian Pacific, including: Alopias pelagicus, Mustelus lunulatus, Sphyrna lewini, Sphyrna tiburo, Mustelus henlei, Carcharhinus porosus and Sphyrna corona.

\begin{tabular}{cccccccc}
\hline Species & A. pelagicus & M. lunulatus & S. lewini & S. tiburo & M. henlei & C. porosus & S. corona \\
\hline A. pelagicus & $*$ & 66.2 & 39.2 & 30.7 & 0.0 & 22.3 & 81.7 \\
M. lunulatus & 6.3 & $*$ & 4.5 & 0.0 & 0.0 & 4.1 & 26.3 \\
S. lewini & 40.9 & 49.3 & $*$ & 0.0 & 24.2 & 95.7 & 9.0 \\
S. tiburo & 10.5 & 0.0 & 0.0 & $*$ & 0.0 & 0.0 & 45.0 \\
M. henlei & 0.0 & 0.0 & 3.9 & 0.0 & $*$ & 16.7 & 0.0 \\
C. porosus & 5.9 & 11.5 & 24.3 & 0.0 & 25.9 & $*$ & 0.0 \\
S. corona & 11.8 & 40.2 & 1.3 & 19.2 & 0.0 & 0.0 & $*$ \\
\hline
\end{tabular}


Table 6. Total mercury ( $\mathrm{THg}$ ) concentrations ( $\left.\mathrm{ng} \mathrm{g}^{-1} \mathrm{ww}\right)$ in fins and muscles of shark species reported in the literature and in this study.

\begin{tabular}{|c|c|c|c|c|c|}
\hline Species & $\mathrm{N}$ & $\begin{array}{c}\mathrm{THg} \\
(\text { mean } \pm \mathrm{SD})\end{array}$ & Tissue & Region & Reference \\
\hline S. zygaena & 37 & 7 & Fins & Baja California Sur, Mexico & Escobar-Sanchéz et al. (2010) \\
\hline C. melanopterus & 26 & $1100 \pm 770$ & Fins & Korean Pacific Ocean & Kim et al. (2016) \\
\hline Prionace glauca & 15 & $2300 \pm 1100$ & Fins & Korean Pacific Ocean & Kim et al. (2016) \\
\hline A. pelagicus & 13 & $1500 \pm 510$ & Fins & Korean Pacific Ocean & Kim et al. (2016) \\
\hline C. longimanus & 4 & $530 \pm 790$ & Fins & Korean Pacific Ocean & Kim et al. (2016) \\
\hline S. zygaena & 3 & $1600 \pm 900$ & Fins & Korean Pacific Ocean & Kim et al. (2016) \\
\hline M. manazo & 2 & $320 \pm 140$ & Fins & Korean Pacific Ocean & Kim et al. (2016) \\
\hline S. tiburo & 18 & $8 \pm 6$ & Fins & Southeastern United States & O'Bryhim et al. (2017) \\
\hline C. porosus & 12 & $67.3-2368.4$ & Fins & Trinidad and Tobago & $\begin{array}{l}\text { Mohammed \& Mohammed } \\
\text { (2017) }\end{array}$ \\
\hline S. lewini & 10 & $301.6-1465.8$ & Fins & Trinidad and Tobago & $\begin{array}{l}\text { Mohammed \& Mohammed } \\
\text { (2017) }\end{array}$ \\
\hline $\begin{array}{l}\text { C. } \\
\text { albimarginatus }\end{array}$ & 26 & $56-32$ & Fins & Revillagigedo Archipelago & Le Croizier et al. (2020) \\
\hline $\begin{array}{l}\text { C. } \\
\text { albimarginatus }\end{array}$ & 28 & $63-48$ & Fins & Clipperton Atoll & Le Croizier et al. (2020) \\
\hline A. pelagicus & 30 & $88.07 \pm 97.66$ & Fins & Colombian Pacific Coast & This study \\
\hline C. porosus & 9 & $45.56 \pm 25.40$ & Fins & Colombian Pacific Coast & This study \\
\hline M. henlei & 25 & $23.45 \pm 15.27$ & Fins & Colombian Pacific Coast & This study \\
\hline M. lunulatus & 20 & $18.38 \pm 11.76$ & Fins & Colombian Pacific Coast & This study \\
\hline S. corona & 10 & $24.10 \pm 16.16$ & Fins & Colombian Pacific Coast & This study \\
\hline S. lewini & 19 & $88.56 \pm 82.30$ & Fins & Colombian Pacific Coast & This study \\
\hline
\end{tabular}




$\begin{array}{lcclll}\text { S. tiburo } & 17 & 34.69 \pm 32.10 & \text { Fins } & \text { Colombian Pacific Coast } & \text { This study } \\ \text { C. falciformis } & 15 & 680 \pm 284 & \text { Muscles } & \text { Baja California Sur, Mexico } & \text { Maz-Courrau et al. (2012) } \\ \text { S. zygaena } & 31 & 196 \pm 184 & \text { Muscles } & \text { Baja California Sur, Mexico } & \text { Maz-Courrau et al. (2012) } \\ \text { S. zygaena } & 37 & 730 & \text { Muscles } & \text { Baja California Sur, Mexico } & \text { Escobar-Sanchéz et al. (2010) } \\ \begin{array}{l}\text { Prionace glauca } \\ \text { S. tiburo }\end{array} & 38 & 1390 \pm 1580 & \text { Muscles } & \text { Baja California Sur, Mexico } & \text { Escobar-Sanchéz et al. (2011) } \\ \text { A. pelagicus } & 42 & 474 \pm 304 & \text { Muscles } & \text { Southeastern United States } & \text { O'Bryhim et al. (2017) } \\ \begin{array}{l}\text { S. lewini } \\ \text { S. lewini }\end{array} & 5 & 994 \pm 720 & \text { Muscles } & \text { South-western Indian Ocean } & \text { Kiszka et al. (2015) } \\ \text { C. porosus } & 6 & 1172 \pm 546 & \text { Muscles } & \text { South-western Indian Ocean } & \text { Kiszka et al. (2015) } \\ \text { S. lewini } & 12 & 120-3328 & \text { Muscles } & \text { Trinidad and Tobago } & \text { Mohammed \& Mohammed } \\ \text { M. henlei } & 10 & 208-1899 & \text { Muscles } & \text { Trinidad and Tobago } & \text { Mohammed \& Mohammed } \\ \text { S. lewini } & 17 & 160 \pm 90 & \text { Muscles } & \text { Pacific Coast of Costa Rica } & \text { Sandoval-Herrera et al. (2016) } \\ \text { A. pelagicus } & 44 & 2718 \pm 1994 & \text { Muscles } & \text { Southwest Indian Ocean } & \text { Le Bourg et al. (2019) } \\ \text { A. pelagicus } & 5 & 4930 \pm 3541 & \text { Muscles } & \text { Southwest Indian Ocean } & \text { Le Bourg et al. (2019) } \\ \text { S. lewini } & 25 & 566.78 \pm & \text { Muscles } & \text { Colombian Pacific Coast } & \text { This study }\end{array}$




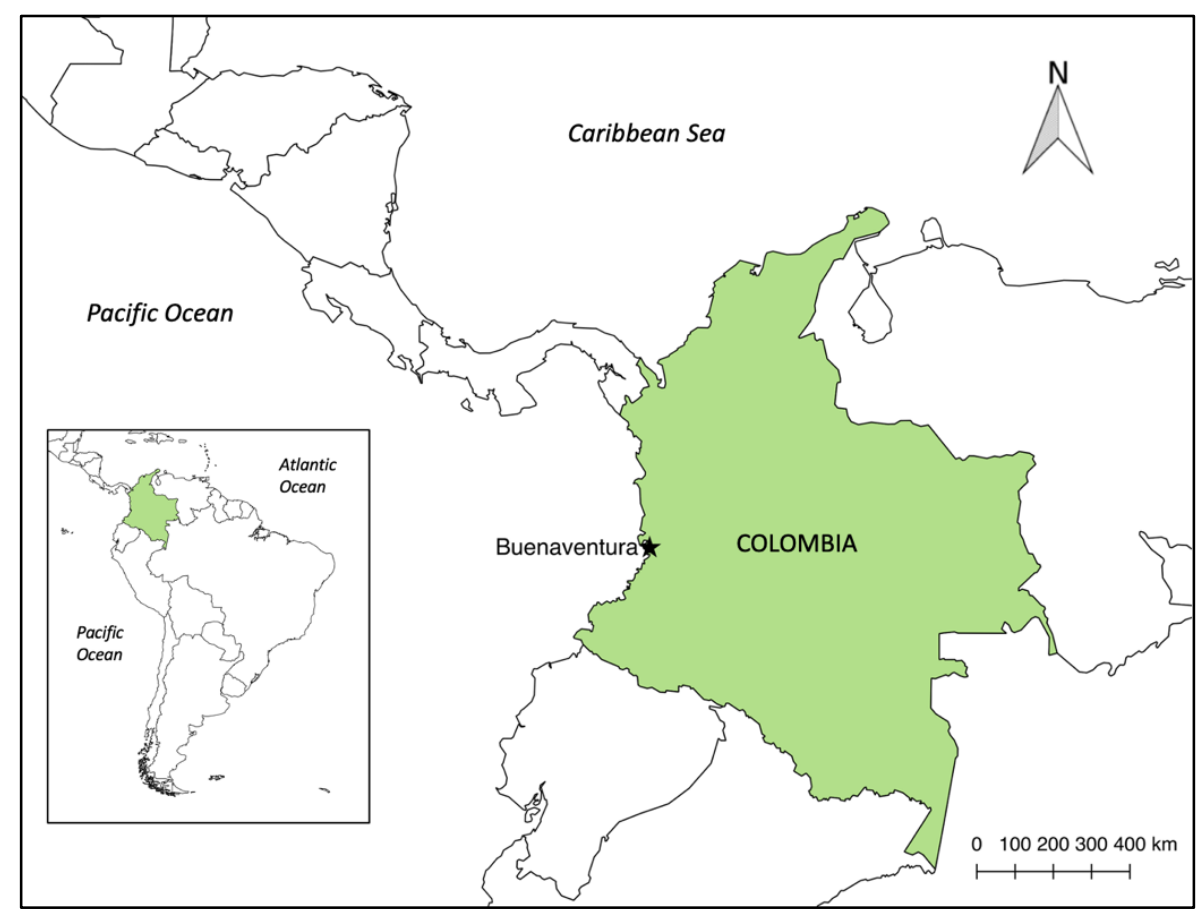

Figure 1. Map of study area showing Buenaventura, where is located the Buenaventura port in the Colombian Pacific coast. Sources: IGAC, modified for this study. 


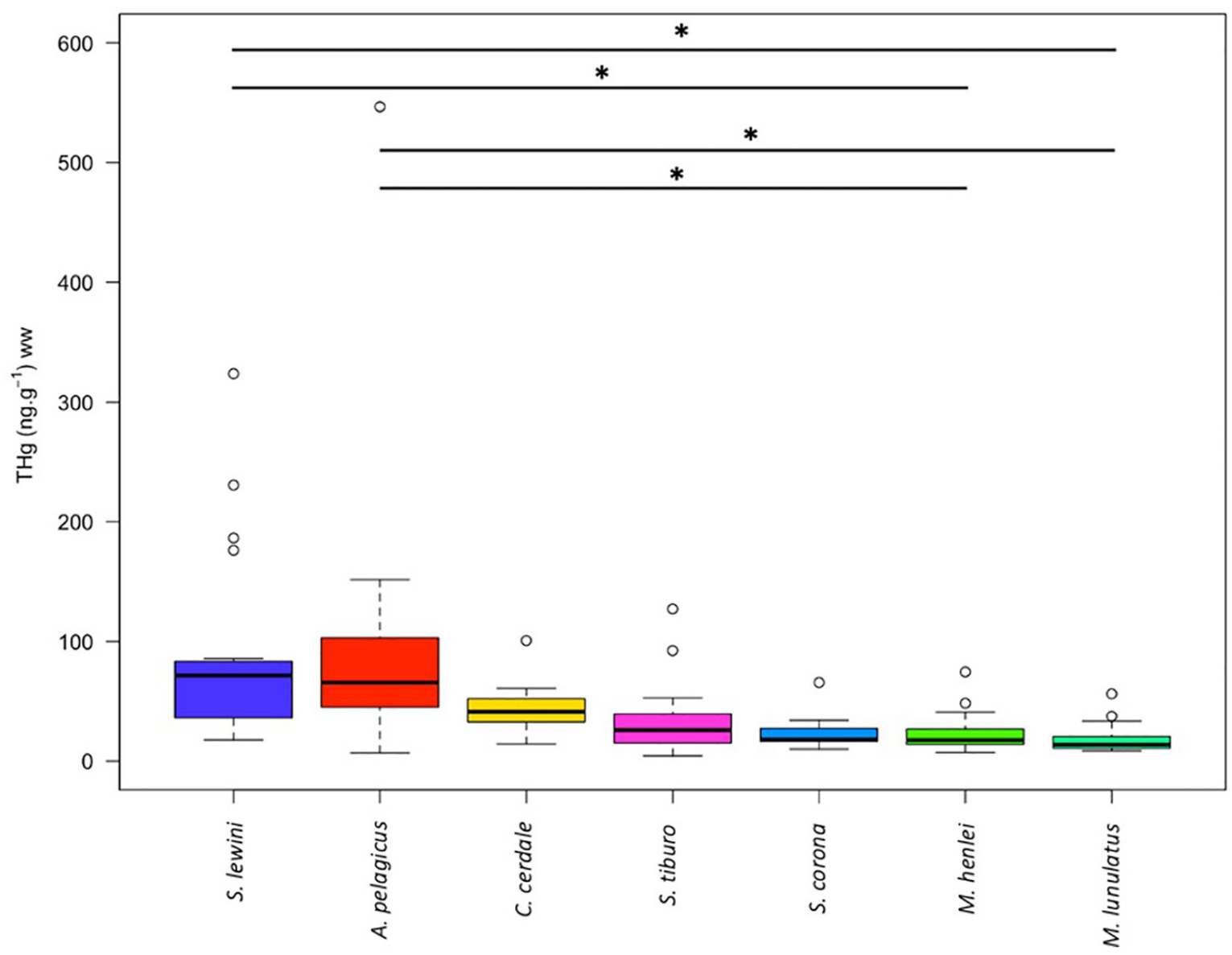

Fig. 2. $\mathrm{THg}$ concentrations (ng $\mathrm{g}^{-1} \mathrm{ww}$ ) in fins of seven shark species of the Colombian Pacific: Alopias pelagicus (red), Carcharhinus porosus (yellow), Mustelus henlei (neon green), Mustelus lunulatus (mint green), Sphyrna corona (blue), Sphyrna lewini (purple) and Sphyrna tiburo (pink). The upper and lower ends of the boxes are the quartiles, the vertical lines are the maximum and minimum, the bold line represents the average and the points are the outliers. The horizontal lines are the paired combinations with significant differences $(*$ : $\mathrm{p}<0.05)$. 


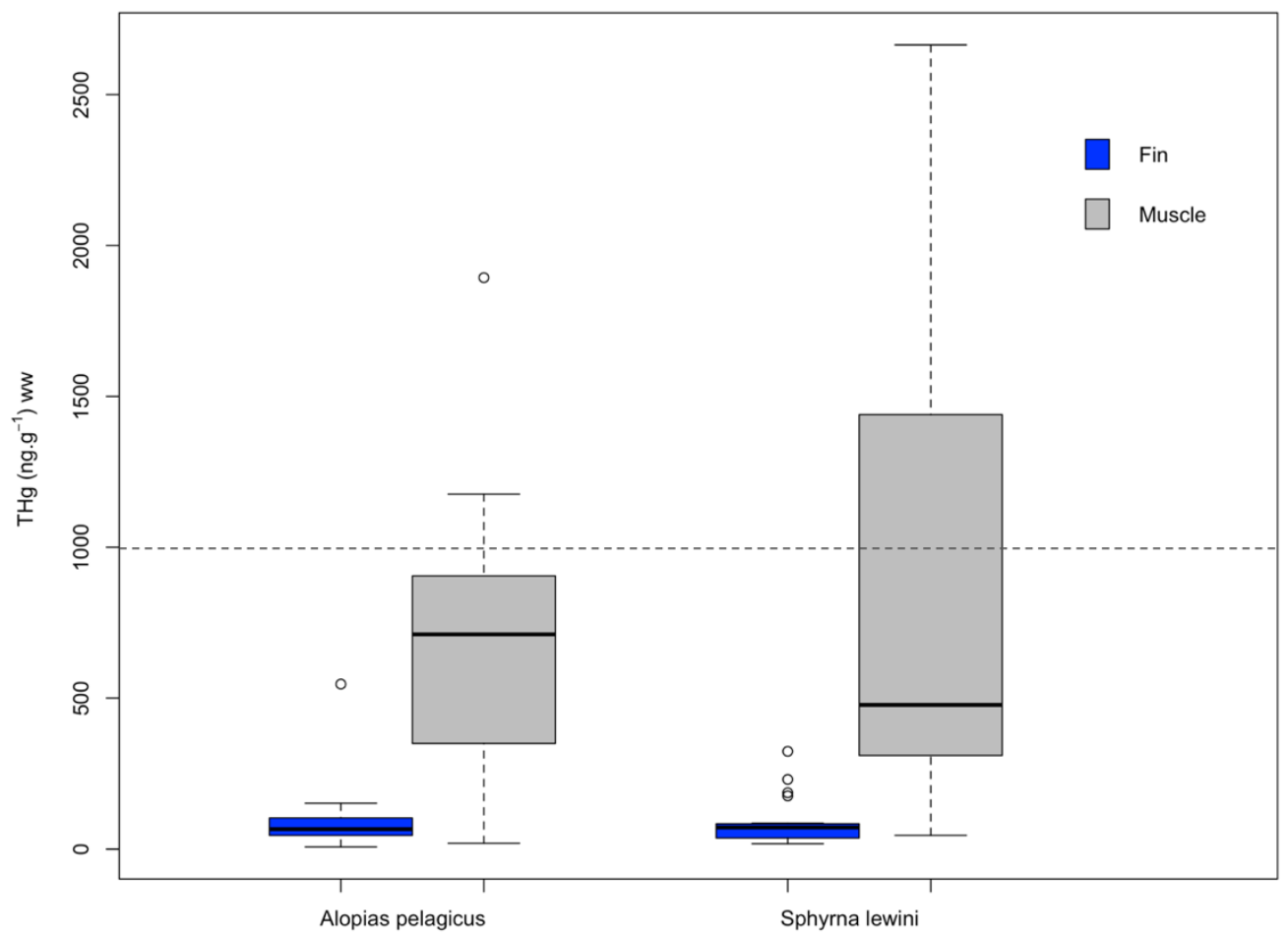

Fig. 3. Fin (blue) and muscle (grey) THg concentrations ( $\mathrm{ng} \mathrm{g}^{-1} \mathrm{ww}$ ) in Alopias pelagicus and Sphyrna lewini individuals of the Colombian Pacific. The upper and lower ends of the boxes are the quartiles, the vertical lines are the maximum and minimum, the bold line represents the average and the points are the outliers. The dotted horizontal line represents the limit of maximum consumption of $\mathrm{Hg}$ in predatory fish recommended by the FAO/WHO (2011). The horizontal lines are the paired combinations with significant differences $(*: \mathrm{p}<$ $0.05)$. 

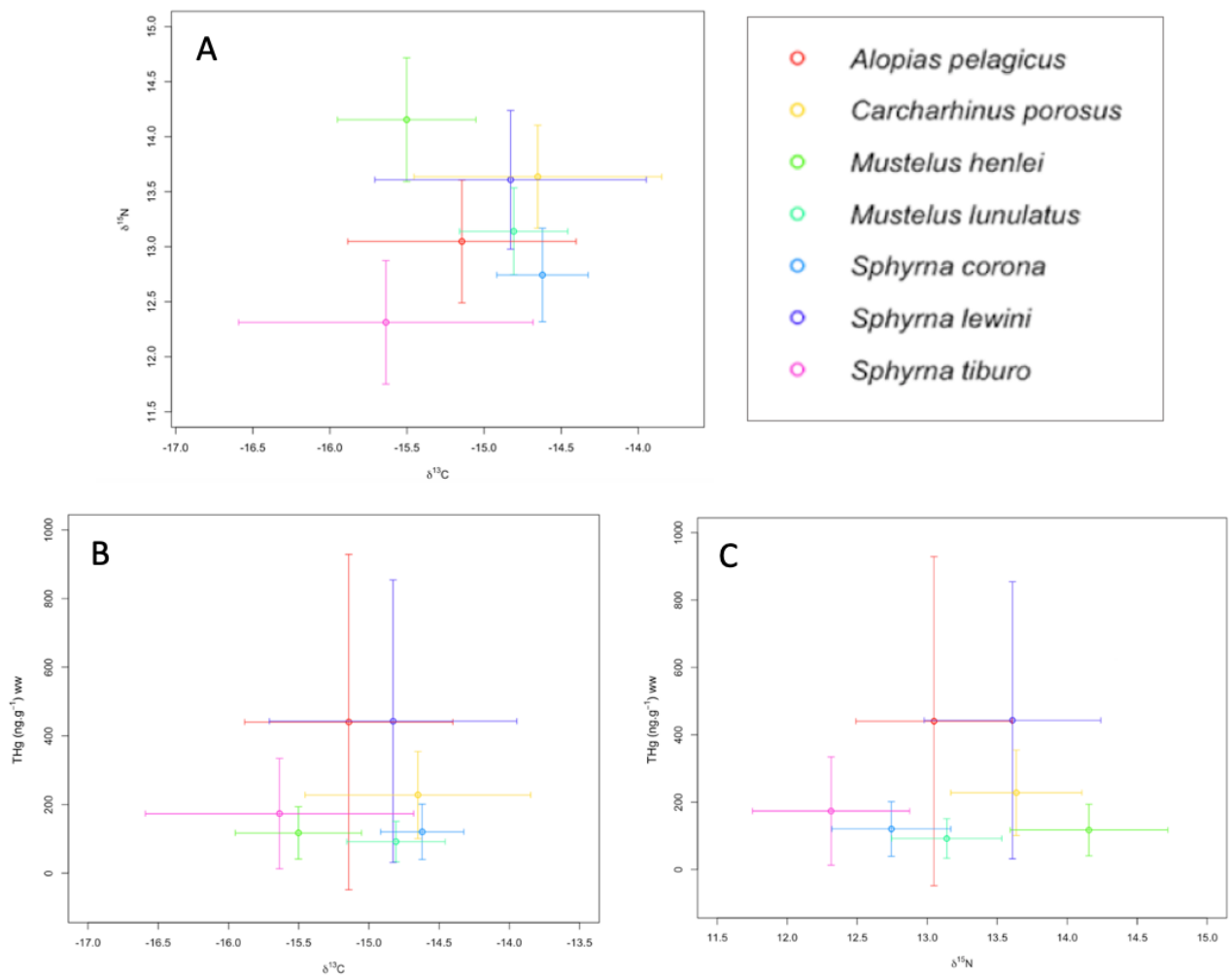

Fig. 4. Relationship (mean $\pm \mathrm{SD}$ ) between carbon and nitrogen isotopic signatures (\%o) and $\mathrm{THg}$ concentrations ( $\mathrm{ng} \mathrm{g}^{-1} \mathrm{ww}$ ) in fins for seven shark species of the Colombian Pacific, including: Alopias pelagicus (red), Carcharhinus porosus (yellow), Mustelus henlei (neon green), Mustelus lunulatus (mint green), Sphyrna corona (blue), Sphyrna lewini (purple) and Sphyrna tiburo (pink). (A) represents relationship between $\delta^{13} \mathrm{C}$ and $\delta^{15} \mathrm{~N}$, (B) $\delta^{13} \mathrm{C}$ and $\mathrm{THg}$ and $(\mathrm{C}) \delta^{15} \mathrm{~N}$ and $\mathrm{THg}$. 

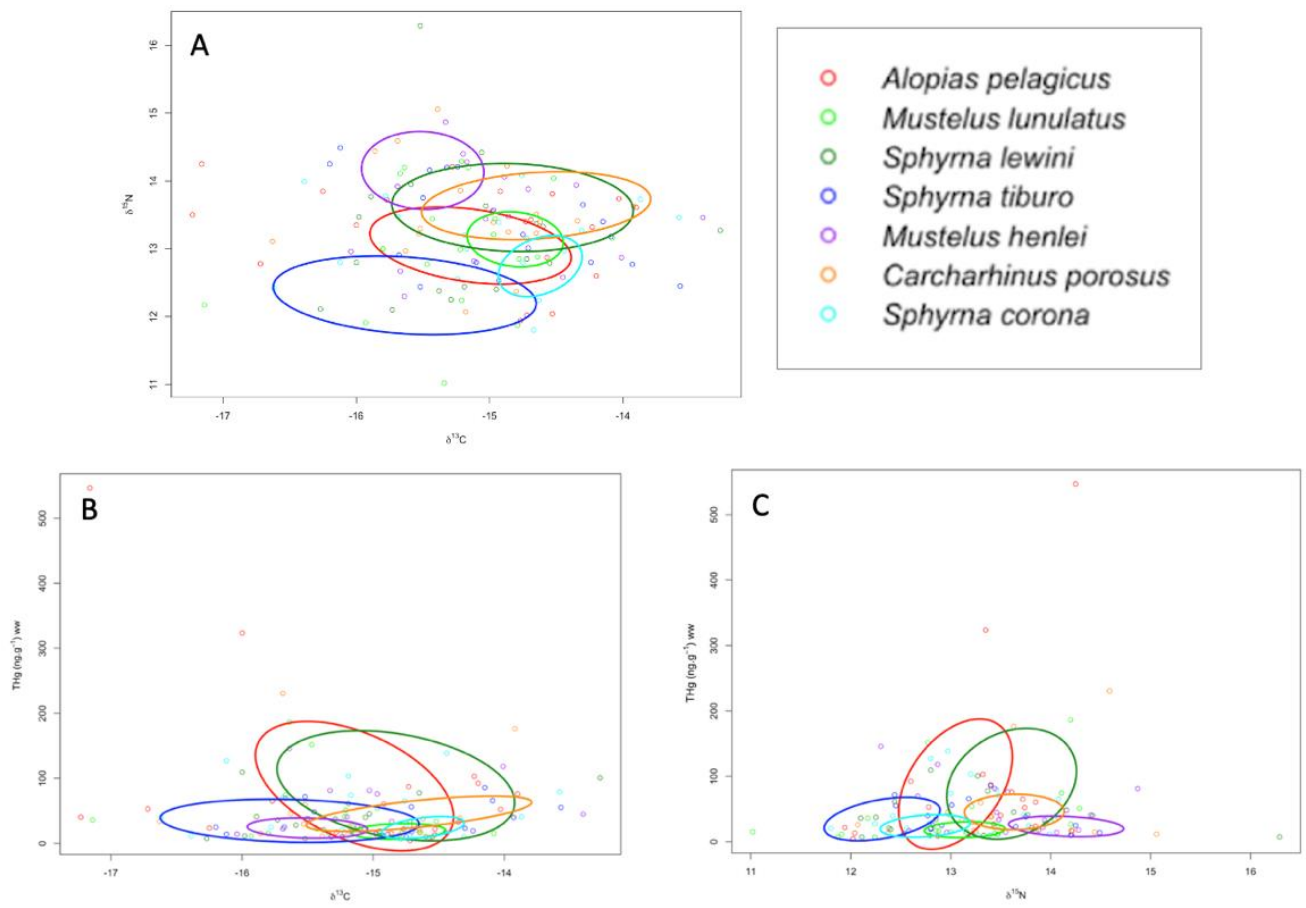

Fig. 5. Standard ellipses for corrected sample sizes (SEAc) of carbon and nitrogen isotopic signatures (\%o) and $\mathrm{THg}$ concentrations ( $\mathrm{ng} \mathrm{g}^{-1} \mathrm{ww}$ ) in fins for seven shark species of the Colombian Pacific, including: Alopias pelagicus (red), Mustelus lunulatus (neon green), Sphyrna lewini (dark green), Sphyrna tiburo (dark blue), Mustelus henlei (purple), Carcharhinus porosus (orange) and Sphyrna corona (neon blue). (A) represents relationship between $\delta^{13} \mathrm{C}$ and $\delta^{15} \mathrm{~N},(\mathrm{~B}) \delta^{13} \mathrm{C}$ and $\mathrm{THg}$ and $(\mathrm{C}) \delta^{15} \mathrm{~N}$ and $\mathrm{THg}$. 


\section{Supplementary material}

Supplementary Table S1. Ecological characteristics and conservation status of seven shark species of the Colombian Pacific studied in this research. Species included Alopias pelagicus, Carcharhinus porosus, Mustelus henlei, Mustelus lunulatus, Sphyrna corona, Sphyrna lewini, and Sphyrna tiburo.






\begin{tabular}{|c|c|c|c|c|c|c|}
\hline & & & & & Pelagic to & \\
\hline & & & Pelagic, & & & Compagno (1984), \\
\hline & & Critically & coastal & $0-$ & & Kimley (1993), \\
\hline & & Endangered & and semi- & 275 & & Hussey et al. (2011), \\
\hline & & & oceanic & & & Rigby et al. (2019a) \\
\hline & & & & & elasmobranchs & \\
\hline & & & Coastal & & & \\
\hline Ponnothond & & I oost & and & & Crustaceans, & Compagno (1984), \\
\hline & S. tiburo & & & $0-80$ & small sized & Cortés et al. (1996), \\
\hline Shark & & Concern & estuarine & & & \\
\hline & & & & & fish & Córtes et al. (2016) \\
\hline & & & waters & & & \\
\hline
\end{tabular}


Supplementary Table S2. Area of corrected standards ellipses (SEAc in $\%^{2}$ ) between $\delta^{13} \mathrm{C}$, $\delta^{15} \mathrm{~N}$ and $\mathrm{THg}$ of fins of seven shark species of the Colombian Pacific, including: Alopias pelagicus, Mustelus lunulatus, Sphyrna lewini, Sphyrna tiburo, Mustelus henlei, Carcharhinus porosus and Sphyrna corona.

Common names $\quad$ Species $\quad \delta^{15} \mathrm{~N} / \delta^{13} \mathrm{C} \quad \mathrm{Hg} / \delta^{13} \mathrm{C} \quad \mathrm{Hg} / \delta^{15} \mathrm{~N}$

$\begin{array}{llccr}\text { Pelagic Thresher } & \text { Alopias pelagicus } & 1.28 & 207.70 & 161.14 \\ \text { Pacific Smalltail Shark } & \text { Carcharhinus cerdale } & 1.32 & 55.70 & 42.61 \\ \text { Brown Smoothhound } & \text { Mustelus henlei } & 0.83 & 22.25 & 27.42 \\ \text { Sicklefin Smoothhound } & \text { Mustelus lunulatus } & 0.45 & 13.52 & 15.26 \\ \text { Scalloped Bonnethead } & \text { Sphyrna corona } & 0.42 & 15.15 & 23.37 \\ \text { Scalloped Hammerhead } & \text { Sphyrna lewini } & 1.84 & 229.45 & 168.14 \\ \text { Bonnethead Shark } & \text { Sphyrna tiburo } & 1.76 & 101.73 & 54.92\end{array}$

